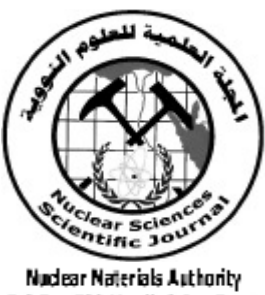

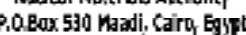

ISSN 2314-5609

Nuclear Sciences Scientific Journal

$8,117-140$

2019

http://www.ssnma.com

\title{
MINERALOGY AND RADIOACTIVITY STUDIES OF WADI ABU HAMUR-SAFAGA STREAM SEDIMENTS, CENTRAL EASTERN DESERT, EGYPT
}

\author{
ASHRAF EL AZAB \\ Nuclear Materials Authority,Cairo, Egypt
}

\begin{abstract}
The studied area covered by igneous and metamorphic rocks represented by Metagabbro, Metavolcanic, Older Granite, Dokhan Volcanics, Hammamat Sediments, and Younger Granite. Faults are essential structural features in the study area. The strike-slip faults of NW trends are right-lateral, while those of E-W, NE, and NNE trends are left-lateral faults. The normal faults are only preserved on a minor scale along these strike-slip faults represented by nearly vertical slicken-sides that indicate substantial vertical displacement.

The grain size analysis and its distribution is a fundamental descriptive measure of clastic sediments. The results of statistical parameters a graphic mean $\left(\mathrm{M}_{2}\right)$ ranging from $0.04 \phi$ to $1.8 \phi$, which means that it lies in coarse and medium sand size classes represented by $70 \%$ and $30 \%$, respectively; inclusive graphic standard deviation $\left(\sigma_{\mathrm{t}}\right)$ ranging from 0.88 to 1.8 . The samples could be categorized in the poorly sorted class and moderately sorted represented by $75 \%$ and $25 \%$, respectively; inclusive graphic Skewness $\left(\mathrm{Sk}_{\mathrm{I}}\right)$ ranging from 0.03 to 0.33 , the samples could be categorized in fine skewed, near symmetrical, and strongly fine skewed classes represented by $55 \%, 40 \%$, and $5 \%$, respectively. Inclusive graphic Kurtosis $\left(\mathrm{K}_{\mathrm{q}}\right)$ ranging from 0.68 to 2.05 , the samples could be categorized in the platykurtic; mesokurtic, very lepto kurtic and lepto kurtic classes represented by $35 \%, 25 \%, 15 \%$ and $25 \%$, respectively.

The average content of total heavy minerals is $4.5 \%$ while the heavy content is ranging from $2 \%$ and $10.5 \%$. Opaque minerals represented by magnetite, hematite, ilmenite constituents have an average of $1.07 \%, 0.1 \%$, and $0.286 \%$, respectively. Abrasive minerals as garnet constituents has an average of $0.13 \%$, and pigment minerals as rutile and titanite constituents have an average of $0.188 \%$, and $0.23 \%$, respectively. Radioactive minerals as fluorites, zircon, and thorite constituents have an average of $0.0075 \%, 0.184 \%$, and $0.001 \%$, respectively. Amphiboles and pyroxene constituents range from $0.1 \%$ to $3.78 \%$ with an average of $2.22 \%$. The eU contents range between 1 and $4 \mathrm{ppm}$ with an average of $1.76 \mathrm{ppm}$, while eTh is between 2 and $29 \mathrm{ppm}$ with an average of $10.75 \mathrm{ppm}$. The average Ra average content for these sediments is $2.89 \mathrm{ppm}$, while the average content of $\mathrm{K} \%$ is $1.16 \%$.
\end{abstract}

\section{INTRODUCTION}

The study area represented by wadi abu hamur-wadi safaga which has long $30 \mathrm{~km}$ and width reach to $50 \mathrm{~m}$ (Fig.1). These wadis lies roughly south of the Safaga-Qena road in unpaved road about $10 \mathrm{~km}$. The study area is bordered to the east by the Tertiary clastics and Cretaceous phosphatic deposits of Wadi Muhammad Rabah. The area are characterized by high rugged topographic area includes different mountains as G. um tagher, G. abu furad, G. wairah and G. muhammad rabah. The area in upstream reaches to $700 \mathrm{~m}$ 
a.s.1. and in downstream reaches to $200 \mathrm{~m}$ a.s.1. at wadi Muhammad rabah and reaches to $4 \mathrm{~m}$ at the end of wadi safaga (um huwaytat) (Figs.2\&3). So the drainage pattern in the area started from the west and ended in the east due to the different in topographic elevation.

The area was originally investigated by
Hume (1934), El-Akkad and Dardir (1965) and Habib (1970, 1972) and forms a part of the region covered by the Safaga Quadrangle 1:100,000 geological map (Dardir et al., 1987), and the Al Qusayr Quadrangle 1:250,000 geological map (Masoud et al.,1992). Fundamental ideas on the relations between gneissic granitoids and supposed older pre-Pan-African

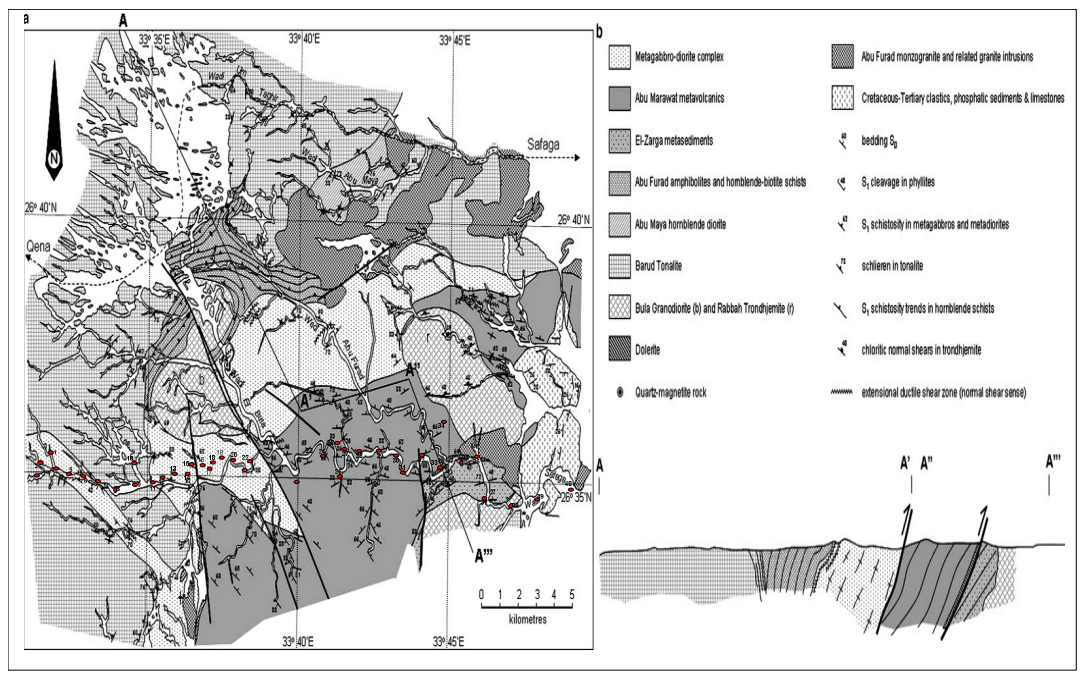

Fig.1: Google map of the area with samples distribution (Modified after Abd El Rahman Fowlar et al., 2006)

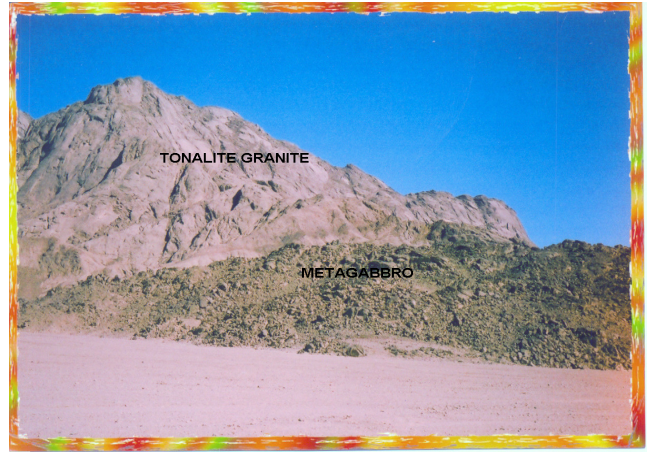

Fig.2:Metagabbro contacted with tonalite granite, Looking North

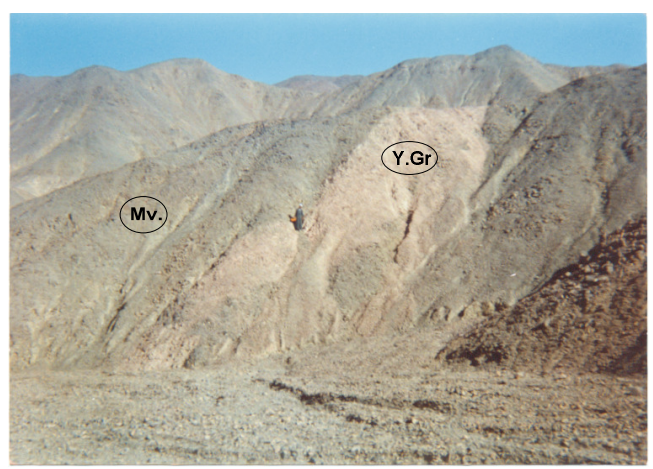

Fig.3:Younger Granite Intruded in Metavolvanics, Looking North 
continental crust were partly based on a study of this area by Akaad et al. (1973). Detailed regional studies have also been completed by El-Gaby and Habib (1980, 1982).

In the following description of the rock units of the area according to the Geological map of Abd El Rahman Fowlar et. Al., 2006, (Fig.1).

\section{GEOLOGIC SETTING}

\section{Metagabbro}

It is present in central part of wadi Abu Hamur and the end of wadi safaga. A wide strip of green-schist facies metamorphosed weakly deformed gabbro.

Massive to weakly deformed gabbro, and form xenoliths in older granites and younger granites. Small intrusions and dyke networks of tonalite, granodiorite, granite, aplite within the mafic rocks are also characteristic (Fig.2).

These mafic intrusive rocks are generally referred to as "metagabbro-diorite complex" or "epidiorite" (El Ramly and Akaad, 1960; Ghanem,1972; Dardir and Abu Zeid, 1972; Francis, 1972; Sabet et al., 1972) though they have also been described as gabbro-diorite-tonalite (GDT) by Abdel-Rahman (1990 \&1995). They are a calc-alkaline series believed to have formed in an intra-oceanic subduction zone environment (Abdel-Rahman, 1990), island arc marginal basin (Ghoneim et al., 1992) or active continental margin setting (El-Gharbawi and Hassen, 2001).

\section{Metavolcanic}

The exposed Metavolcanics in the study area represent a part of geosynclinal volcanic activity (El Shazly, 1964). According to the latter author, the main geosynclinal volcanics can be distinguished into an older basic series, associated with ultramafics, and a younger series of intermediate composition dominated by andesite together with subordinate diabase and tuffs. Stern (1981) divided the Metavol- canics cropping out in the area between lat. $25^{\circ} 30^{\prime}$ and $26^{\circ} 30^{\prime} \mathrm{N}$ in the Eastern Desert into Older Metavolcanics (OMV) and Younger Metavolcanics (YMV). It covered the vast part of wadi safaga and the mouth of wadis Al Bulah and Abu Furad. The metavolcanics intruded by younger granite (Fig.3).

\section{Tonalites}

They covered the wadi Abu Hamur, highly weathered and fractured. It is represented by calc-alkaline foliated (tonalite) rock (Fig.4). This rock is highly fractured and cutted by numerous acidic dikes (felsites and feldspar) (Figs.5\&6).

\section{Dokhan Volcanics}

It represented by Calc-alkaline andesitic to rhyolitic rocks. They are located at the end of wadi safaga contacted by metagabbro (Fig. 1).

\section{Hammamat Sediments}

It located in wadi safaga and extended to south in wadi wasif. The Hammamat metasediments consist mainly of planar bedded and laminated greyish to greenish metasiltstone, phyllite and greywacke with minor conglomerate. Graded bedding in the sandstone metasediments indicates consistent upward younging for the sequence (Fig.7 ).

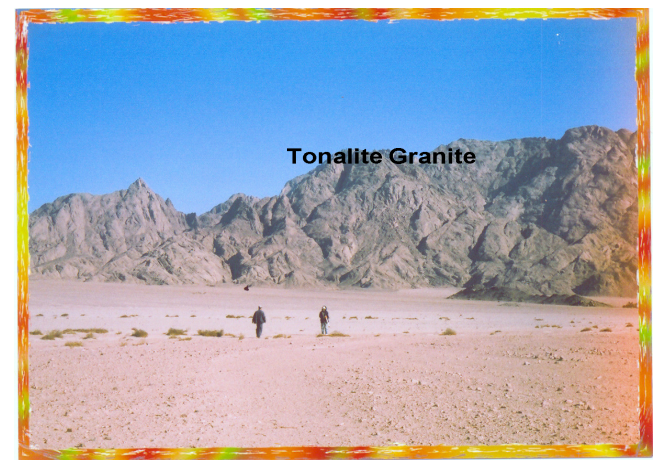

Fig.4:Tonalite Granite in Wadi Abu Hamur, looking North 


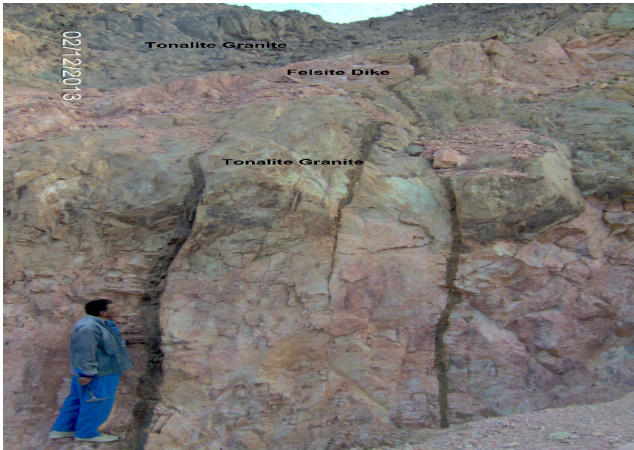

Fig.5:Felsite dike intruded in tonalite granite

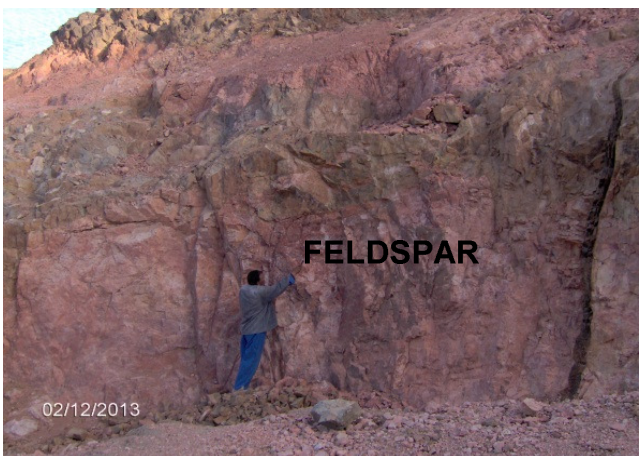

Fig.6:Feldspar intruded in tonalite Granite in Wadi Abu Hamur, Looking south

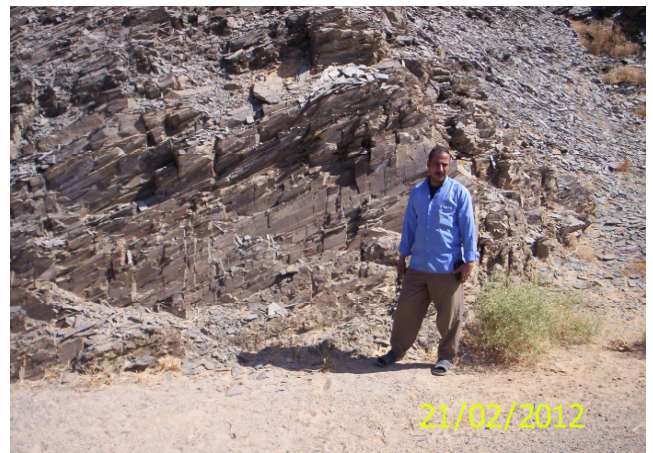

Fig.7:Hammamat sediments in Wadi Safaga, Looking South

\section{EL AZAB}

\section{Younger Granite}

This granite restricted in the mouth of wadi safaga. This rock type represented by calc-alkaline, weakly deformed, and deeply weathered (Fig.8). It is intruded in all oldest rocks and intruded by acidic dykes (Fig. 9).

\section{Structure}

Faults are essential structural features in the study area (Fig.10). These faults have been well studied in the present work, with emphasis on fault slip. Slickensides and grooves are commonly associated with brittle

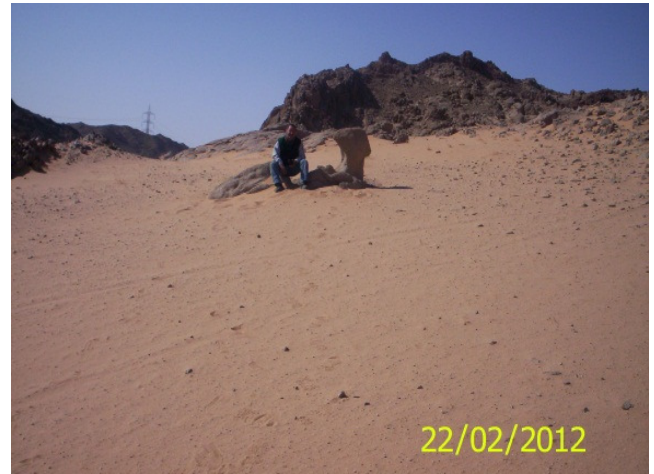

Fig.8:Weathering of Younger Granite in Wadi Safaga, Looking North

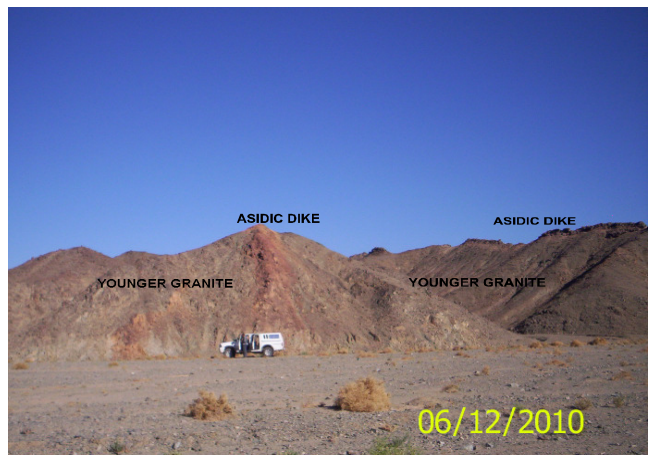

Fig.9:Acidic Dike intruded in Younger Granite 


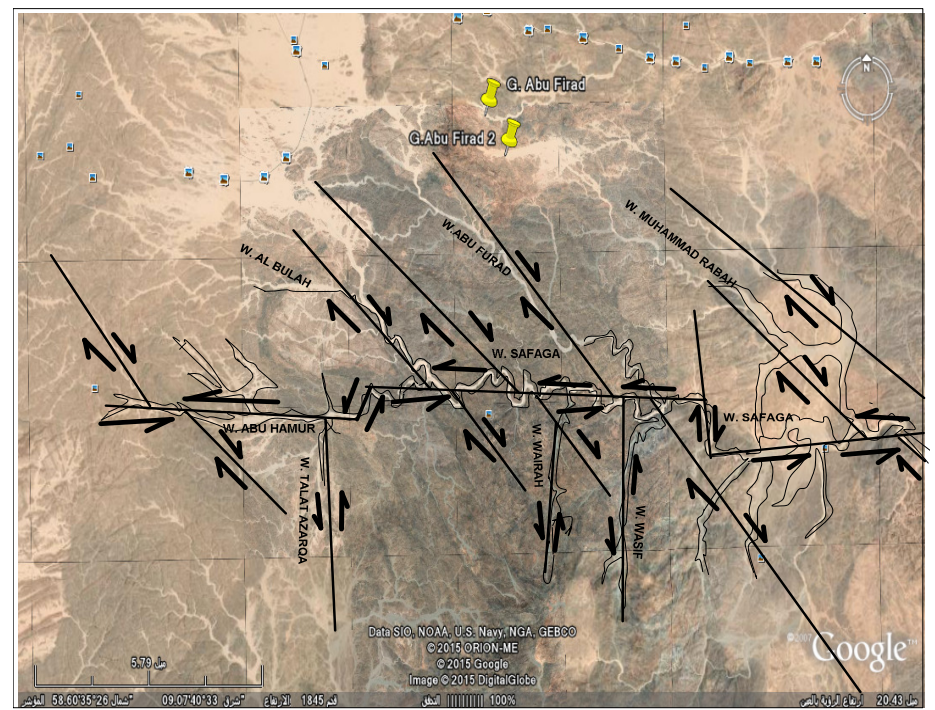

Fig.10: Structure map of the area

faulting. These kinematic indicators indicate the direction and sense of maximum resolved shear stress in that plane (Carey and Brunier, 1974). Slickensides are often composed of fibrous crystals of chlorite, epidote, calcite and quartz that stretch from one side of the fault plane to the other (Fig.11).

The strike-slip faults of NW trends are right-lateral, while those of $\mathrm{E}-\mathrm{W}, \mathrm{NE}$, and NNE trends are left-lateral faults. These strike-slip faults dislocate the intrusive rocks. Fortunately, the rock exposures provided criteria to evaluate the activity along these faults in chronological order. The NW-trending faults are the oldest fracture planes, followed by the faults of E-W orientation, and ending with the NNE-trending faults (Fig.10). The NNE-trending faults dislocate the older, differently oriented faults. The normal faults are only preserved on a minor scale along these strike-slip faults represented by nearly vertical slickensides that indicate to substantial vertical displacement.

\section{SAMPLING AND TECHNIQUES}

A total of 40 stream sedimentary samples were collected from Wadi Abu Hamur-Wadi Safaga through an open bit samples of $50 \mathrm{~cm}$ diameter and depth of about $80 \mathrm{~cm}$., the samples spacing were $750 \mathrm{~m}$ apart (Fig.1). The average weight of each sample is about $10 \mathrm{~kg}$. The obtained samples were dried, sieved using $2 \mathrm{~mm}$ sieve to remove gravel fraction and the rest of samples were quartered to obtain representative from $120 \mathrm{gm}$ up to $200 \mathrm{gm}$ from each. The representative samples were prepared for mechanical analysis and mineralogical investigation, where most of the silt and all of the clay were removed by decantation method. A representative sub-sample weighting about $60 \mathrm{gm}$ was taken from each prepared sample and subjected to grain size analysis. The different percentiles were obtained in phi units from the cumulative curves using the phi scale. The four sedimentological statistical parameters namely: the Graphic Mean $\left(\mathrm{M}_{\mathrm{z}}\right)$, the Inclusive Graphic Standard Deviation $\left(\sigma_{\mathrm{I}}\right)$, the Inclusive Graphic Skewness $\left(\mathrm{Sk}_{\mathrm{I}}\right)$, and the Graphic Kurtosis $\left(\mathrm{K}_{\mathrm{G}}\right)$ were 


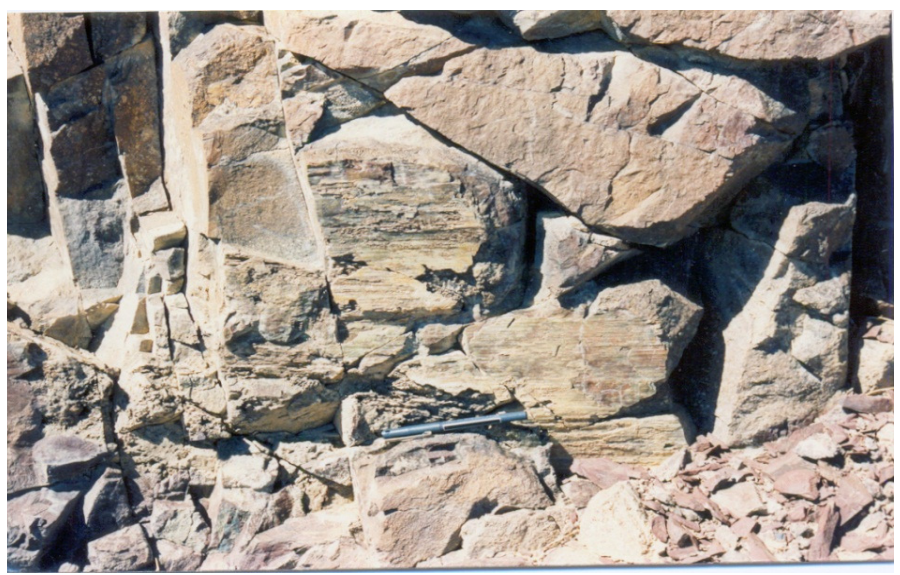

Fig.11:Slickensides on the fault plane

calculated for each sample, according to the equations quoted by Folk and Ward (1957). The calculated grain size statistical parameters for the sand size fraction are represented in Table (1).

Quantitative mineralogical analyses for the stream sedimentary samples were carried out by gravity separation using a Wilfley Shaking Table (Size No.13), heavy liquid separation using bromoform solution (Sp. Gr. $2.86 \mathrm{~g} / \mathrm{cm}^{3}$ ), methylene iodide (Sp. Gr. $3.3 \mathrm{~g} / \mathrm{cm}^{3}$ ), and magnetic fractionation using a Frantz Isodynamic Magnetic Separator (Model L-1) to fractionate heavy minerals according to their magnetic susceptibilities. First, magnetite was collected by a hand magnet, and then the magnetite free samples were subjected to the magnetic separation. The condition characterized a Frantz Isodynamic Magnetic Separator transvers slop 5, longitudinal slop 20 and step of current $0.2,0.5,1.0,1.5$ magnetic and 1.5 non magnetic current amperes.

Each fraction obtained from the magnetic separation process was microscopically studied under binocular stereomicroscope and investigated to calculate the frequency distribution of the concerned minerals in the studied stream sediment samples.
Mineralogical investigation of the mineral constituents of the stream sediments of Wadi Abu Hamur-Wadi Safaga was carried out by X-ray diffraction technique. A Phillips X-ray diffractometer (Model PW-1010) with a scintillation counter (Model PW-25623/00) and Ni filter was used. Semi-quantitative EDX chemical analyses were carried out using a Phillips XL-30 Environmental Scanning Electron Microscope (ESEM).

Determinations of the eU, eTh, Ra (ppm) and $\mathrm{K}(\%)$ concentrations of the studied stream sediments were carried out using a Bicron Scintillation Detector NaI (TI) 76x76mm. They were packed in plastic containers, sealed carefully, and stored for thirty days prior to counting.

\section{RESULTS}

\section{Grain Size Analyses}

The grain size analysis and its distribution is a fundamental descriptive measure for clastic sediments. It is an important parameter in understanding and interpreting the operative mechanism during transportation and for reflecting the sedimentary environments and the processes of sedimentation, as well as, the dynamics affecting of the area. 
The four different sedimentological statistical parameters namely: the Graphic Mean $\left(\mathrm{M}_{\mathrm{z}}\right)$, the Inclusive Graphic Standard Deviation $\left(\sigma_{\mathrm{f}}\right)$, the Inclusive Graphic Skewness $\left(\mathrm{Sk}_{\mathrm{I}}\right)$, and the Graphic Kurtosis $\left(\mathrm{K}_{\mathrm{G}}\right)$ were calculated for each sample, according to the equations quoted by Folk and Ward (1957) as follows:

-Graphic Mean $\left(\mathrm{M}_{\mathrm{z}}\right)=(\phi 16+\phi 50+\phi 84) / 3$ -Inclusive Graphic Standard Deviation $\left(\sigma_{\mathrm{I}}\right)=$ $[(\phi 84-\phi 16) / 4]+[\phi 95-\phi 5) / 6.6]$ -Inclusive Graphic Skewness $\left(\mathrm{Sk}_{\mathrm{I}}\right)=$

: $[\phi 16+\phi 84-2 \phi 50) / 2(\phi 84-\phi 16)]+[(\phi 5+\phi 95-2 \phi 50) / 2(\phi 95-\phi 5)]$
-Graphic Kurtosis $\left(\mathrm{K}_{\mathrm{G}}\right)=(\phi 95-\phi 5) / 2.44(\phi 75-\phi 25)$

The grain size parameters $\left(\mathrm{Mz}, \sigma_{\mathrm{I}}, \mathrm{Sk}_{\mathrm{I}}, \mathrm{K}_{\mathrm{G}}\right)$ were calculated, and the results of these parameters are discussed, and described according to the limits of Folk and Ward (1957), and tabulated in (Table 1) as the follows:

The samples have a graphic mean $\left(\mathrm{M}_{\mathrm{z}}\right)$ ranging from $0.04 \phi$ to $1.8 \phi$ (Table 1) which means that it lies in coarse and medium sand size classes represented by $70 \%$ and $30 \%$ respectively (Table 2).

The samples have inclusive graphic stan-

Table 1:Grain size parameters of the studied samples

\begin{tabular}{|c|c|c|c|c|c|c|c|c|}
\hline Sample & & Iean Size (Mz) & Stand: & 1 Deviation $(\sigma)$ & & Skewness (SKI). & & Kurtosis (KG) \\
\hline & 1.8 & Medium sand & 1.7 & Poorly sorted & 0.16 & Fine skewed & 0.68 & Platy kurtic \\
\hline 2 & 1.4 & & 1.6 & rted & 0.04 & Near sym & 0.84 & Plat. \\
\hline 3 & 1.3 & Medium sand & 1.5 & Poorly sorted & 0.06 & Near symmetrical & 0.77 & Platy kurtic \\
\hline 4 & 0.95 & Coarse sand & 1.4 & Poorly sorted & 0.17 & Fine skewed & 0.88 & Platy kurtic \\
\hline $\mathbf{5}$ & 1.6 & Medium sand & 1.8 & orted & 0.03 & Near symmetrical & 0.94 & Meso kurtic \\
\hline 6 & 1.1 & Medium sand & 1.4 & Poorly sorted & 0.13 & Fine skewed & 0.86 & Platy kurtic \\
\hline 7 & 0.8 & Coarse sand & 1.2 & Poorly sorted & 0.08 & Near symmetrical & 1.02 & Meso kurtic \\
\hline 8 & 0.3 & Coarse sand & 1.1 & Poorly sorted & 0.05 & Near symmetrical & 0.82 & Platy kurtic \\
\hline 9 & 0.6 & Coarse sand & 1.2 & Poorly & 0.03 & Near symmetrical & 1.26 & Lepto kurtic \\
\hline 10 & 0.3 & Coarse sand & 0.92 & Moderately & 0.23 & Fine skewed & 1.54 & Very lepto \\
\hline 11 & 0.04 & Coarse sand & 1.1 & Poorly sorted & 0.15 & Fine & 1.09 & urtic \\
\hline 12 & 0.05 & Coarse sand & 1.1 & Poorly sorted & 0.26 & Fine skewed & 1.15 & Lepto kurtic \\
\hline 13 & 0.10 & Coarse sand & 1.8 & Poorly sorted & 0.21 & Fine skewed & 1.13 & Lepto kurtic \\
\hline 14 & 0.18 & Coarse sand & 1.4 & Poorly sorted & 0.22 & Fine skewed & 1.11 & Meso kurtic \\
\hline 15 & 0.19 & Coarse sand & 0.94 & Moderately & 0.13 & kewed & 1.59 & Very lepto \\
\hline 16 & 1.33 & Medium sand & 1.3 & Poorly & 0.08 & Near sym & 0.89 & Platy kurtic \\
\hline 17 & 0.10 & Coarse sand & 1.3 & Poorly & 0.33 & ly fine & 1.15 & Lepto kurtic \\
\hline 18 & 0.17 & Coarse sand & 0.9 & Mod & 0.21 & kewed & 2.05 & lepto \\
\hline 19 & 0.15 & Coarse sand & 0.97 & Moderately & 0.15 & Fine skewed & 1.23 & Lepto kurtic \\
\hline 20 & 0.13 & e sand & 0.88 & Mod & 0.09 & Near sym & 1.04 & Meso \\
\hline 21 & 1.7 & Medium sand & 1.72 & Poorly & 0.17 & Fine skewed & 0.71 & Platy kurtic \\
\hline 22 & 1.5 & Medium sand & 1.63 & Po & 0.05 & Near sym & 0.82 & Platy kurtic \\
\hline 23 & 1.4 & Medium sand & 1.51 & Poorly & 0.05 & Near symmetrical & 0.75 & Platy kurtic \\
\hline 24 & 0.9 & Coarse sand & 1.42 & Poorly sorted & 0.18 & kewed & 0.89 & Platy kurtic \\
\hline 25 & 1.61 & Medium sand & 1.7 & Poorly sorted & 0.05 & Near symmetrical & 0.96 & Meso kurtic \\
\hline 26 & 1.12 & Medium sand & 1.5 & Poorly sorted & 0.13 & Fine skewed & 0.88 & urtic \\
\hline 27 & 0.9 & sand & 1.2 & ted & 0.09 & Near syr & 1.03 & rtic \\
\hline 28 & 0.31 & Coarse sand & 1.2 & Por & 0.04 & Near sym & 0.84 & Platy kurtic \\
\hline 29 & 0.62 & Coarse sand & 1.4 & Poor & 0.03 & Near symmetrical & 1.27 & Lepto kurtic \\
\hline 30 & 0.31 & Coarse sand & 0.95 & ately & 0.24 & Fine skewed & 1.6 & Very lepto \\
\hline 31 & 0.06 & Coarse sand & 1.14 & Poorly sorted & 0.16 & wed & 1.1 & Meso kurtic \\
\hline 32 & 0.05 & Coarse sand & 1.13 & Poorly & 0.28 & kewed & 1.14 & kurtic \\
\hline 33 & 0.11 & Coarse sand & 1.81 & ted & 0.23 & wed & 1.15 & Lept \\
\hline 34 & 0.17 & Coarse sand & 1.5 & Poorly sorted & 0.24 & kewed & 1.12 & Meso kurtic \\
\hline 35 & 0.19 & Coarse sand & 0.96 & Moderately & 0.15 & Fine skewed & 1.57 & Very lepto \\
\hline 36 & 1.4 & Medium sand & 1.35 & ted & 0.09 & Near symmetrical & 0.99 & Platy kurtic \\
\hline 37 & 0.12 & $\mathrm{Co}$ & 1.4 & Poo & 0.34 & & 1.16 & Lep \\
\hline 38 & 0.19 & Coarse sand & 0.92 & & 0.22 & kewed & 2.1 & Very lepto \\
\hline 39 & 0.14 & Coarse sand & 0.87 & Moderately & 0.15 & Fine skewed & 1.21 & Lepto kurtic \\
\hline 40 & 0.13 & Coarse sand & 0.89 & Moderately & 0.09 & Near symmetrical & 1.05 & Meso kurtic \\
\hline
\end{tabular}


dard deviation $\left(\sigma_{\mathrm{I}}\right)$ ranging from 0.88 to 1.8 (Table 1), the samples could be categorized in the poorly sorted class and moderately sorted represented by $75 \%$ and $25 \%$, respectively (Table 2).

The samples have inclusive graphic Skewness $\left(\mathrm{Sk}_{\mathrm{r}}\right.$ ) ranging from 0.03 to 0.33 (Table 1 ), the samples could be categorized in fine skewed, near symmetrical, and strongly fine skewed classes represented by $55 \%, 40 \%$, and $5 \%$, respectively (Table 2 ).

The samples have inclusive graphic Kurtosis $\left(\mathrm{K}_{\mathrm{g}}\right)$ ranging from 0.68 to 2.05 (Table $1)$, the samples could be categorized in the platykurtic, mesokurtic, very lepto kurtic and lepto kurtic classes represented by $35 \%, 25 \%$ , 15\% and $25 \%$, respectively (Table 2).

Shape and size are quite important for measuring of the textural maturity of the sediment and the texture as a key of the sedimentary deposit history. So the sorting is reflected the sedimentary history of the deposit. It shows the nature and magnitude of the weathering (transportation, and deposition processes and their duration). The sediments are characterized by poorly to moderately sorted sediment texture and medium to coarse grain size that reflect their immature texture.

The skewness is a measure of the symmetry of the frequency curve. The frequency curve is represented by bolymodal. The bimodal curve may be due to the following:
a)Effect of source rock: by mechanical weathering of rocks such as granite where two major size are present (medium and coarse), the resulting sediments will have two large amounts related to the two different major sizes (bimodal).

b)Turbulant transportation: Turbidity currents can cause the admixing of sediments from different environments. Turbulent flow is a motion in which velocity fluctuates and direction changes during flow. The material carried is usually of mixed nature and accordingly of less sorted type. The turbulent flow is the ability to carry coarse-grained materials.

\section{EVALUATION OF THE STREAM SEDIMENTS}

\section{Heavy Minerals Distribution}

To obtain the heavy minerals from the studied stream sediment samples gangue minerals should be removed, especially quartz and feldspars which constitute more than $90 \%$ of the stream sediments of Wadi Abu HamurSafaga by using the shaking table, then path through the heavy liquid as bromoform and methyline.

The percent of the heavy minerals content in the studied stream sediments are tabulated in Table 3. The heavy minerals content ranging from $2 \%$ and $10.5 \%$ with an average of $4.5 \%$ (Fig. 12 ).

Table 2: Distribution of the different calculated grain size parameters of the studied samples among the different classes

\begin{tabular}{lcrrrrrr}
\hline \multicolumn{2}{l}{ Graphic Mean $\mathrm{M}_{\mathrm{z}}$} & \multicolumn{2}{c}{ Inclusive Graphic } & The Inclusive Graphic & \multicolumn{2}{c}{ The Inclusive Kurtosis } \\
\hline Class & $\%$ & Class & $\%$ & Class & $\%$ & Class & $\%$ \\
Coarse & $\mathbf{7 0}$ & Poorly sorted & 75 & Fine skewed & $\mathbf{5}$ & Platykurtic & 35 \\
Medium & $\mathbf{3 0}$ & Moderately sorted & 25 & Near symmetrical & 4 & Mesokurtic & 25 \\
& & & & Strongly fine skewed & $\mathbf{5}$ & Very lepto kurtic & 15 \\
& & & & & Lepto kurtic & 25 \\
\hline
\end{tabular}


The high content of the heavy minerals in the studied stream sediments restricted in some localities near the acidic rocks.

The obtained fractions were weighted and their percentages were calculated (Table 4). It

Table 3: The percentages of the heavy minerals in the studied stream sediments of Wadi Abu Hamur-Safaga after Bromoform

\begin{tabular}{|c|c|c|c|c|c|}
\hline $\begin{array}{l}\text { Name of } \\
\text { Wadi } \\
\end{array}$ & $\begin{array}{l}\text { S. } \\
\text { No. }\end{array}$ & $\begin{array}{r}\text { Heavy Min. } \\
\% \\
\end{array}$ & $\begin{array}{r}\text { Name of } \\
\text { Wadi } \\
\end{array}$ & S. No. & $\begin{array}{r}\text { Heavy Min. } \\
\% \\
\end{array}$ \\
\hline \multirow[t]{11}{*}{ Abu Hamur } & 1 & 5.01 & Safaga & 21 & 3.17 \\
\hline & 2 & 7.21 & & 22 & 3.041 \\
\hline & 3 & 5.71 & & 23 & 3.841 \\
\hline & 4 & 7.03 & & 24 & 4.11 \\
\hline & 5 & 6.74 & & 25 & 3.91 \\
\hline & 6 & 7.12 & Abu Furad & 26 & 4.01 \\
\hline & 7 & 6.44 & Safaga & 27 & 2.96 \\
\hline & 8 & 9.62 & & 28 & 3.14 \\
\hline & 9 & 4.83 & & 29 & 4.03 \\
\hline & 10 & 4.22 & & 30 & 4.38 \\
\hline & 11 & 5.1 & & 31 & 4.07 \\
\hline El Bula & 12 & 5.3 & & 32 & 3.93 \\
\hline \multirow[t]{8}{*}{ Safaga } & 13 & 6.22 & & 33 & 4.78 \\
\hline & 14 & 6.19 & & 34 & 1.77 \\
\hline & 15 & 4.66 & & 35 & 2.632 \\
\hline & 16 & 3.93 & & 36 & 3.152 \\
\hline & 17 & 3.75 & & 37 & 3.982 \\
\hline & 18 & 4.13 & & 38 & 4.322 \\
\hline & 19 & 2.57 & & 39 & 4.712 \\
\hline & 20 & 2.29 & & 40 & 5.112 \\
\hline Min. & & & & & 1.77 \\
\hline Max. & & & & & 9.62 \\
\hline Ave. & & & & & 4.58 \\
\hline
\end{tabular}

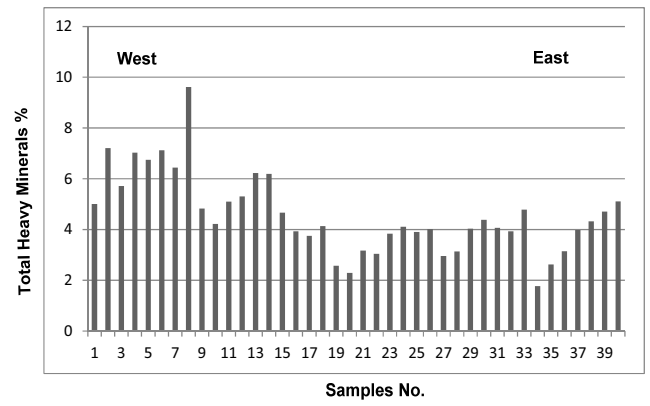

Fig.12:Histogram show the distribution of total heavy minerals in the study area is obviously noted that the heavy minerals are concentrated mainly in 0.2 amp and $0.5 \mathrm{amp}$ magnetic fractions; while $1.5 \mathrm{amp}$ magnetic and non-magnetic fractions contains the lowest concentration of the heavy minerals.

A considerable number of grains from each magnetic fraction were counted (about 1500 grains). The weight percentage of each concerned mineral relative to the corresponding original sample was calculated according to Stakhove equation:

$$
\mathrm{Q}=\left[\mathrm{P} . \mathrm{n}_{\mathrm{m}} \cdot \mathrm{d}_{\mathrm{m}} / \Sigma\left(\mathrm{n}_{\mathrm{o}} \mathrm{d}_{\mathrm{o}}\right)\right] .100
$$

Where: $\mathrm{Q}=$ the weight percentages of the concerned mineral

$\mathrm{P}=$ the weight percentage of the corresponding magnetic fraction.

$\mathrm{n}_{\mathrm{m}}=$ the number of grains of the mineral.

$\mathrm{d}_{\mathrm{m}}=$ specific gravity of the mineral.

$\Sigma\left(\mathrm{n}_{\mathrm{o}} \mathrm{d}_{\mathrm{o}}\right)=$ the sum of the number of grains for each mineral multiplied by its specific gravity.

The common heavy minerals in the studied stream sediments are zircon, titanite, monazite, garnet, rutile, fluorite, thorite, green silicates (amphipoles \& pyroxenes) in addition to opaque minerals magnetite, ilmenite and hematite (Tables 5 a \& b).

\section{Iron Oxides Minerals \\ Magnetite}

It represents the major part of opaque grains of the studied samples. It is black granular masses (Fig.13), and strongly magnetic, sometimes with zircon or garnet inclusions. It separated using small hand magnet. These mineral constituents range from $0.1 \%$ to 2.3 $\%$ with an average $1.07 \%$, and are represented by histogram (Fig.14).

The low uranium and thorium contents in magnetite of the stream sediments indicate that uranium in magnetite is mostly of the adsorbed type which is liable and easily leachable under the weathering conditions 
Table 4:Frequency of the heavy minerals in the different magnetic fractions

\begin{tabular}{|c|c|c|c|c|c|c|}
\hline S. No. & $\begin{array}{r}\text { Magn. } \\
\%\end{array}$ & $\begin{array}{r}\text { 0.2 } \\
\text { mag. } \\
\%\end{array}$ & $\begin{array}{r}0.5 \text { mag. } \\
\%\end{array}$ & $\begin{array}{r}1.0 \text { mag. } \\
\%\end{array}$ & $\begin{array}{r}1.5 \\
\text { mag. } \\
\%\end{array}$ & $\begin{array}{r}1.5 \\
\text { Non } \\
\text { mag. } \\
\%\end{array}$ \\
\hline S1 & 15.6 & 33.8 & 43.6 & 3.20 & 0.72 & 2.031 \\
\hline S2 & 35.95 & 24.6 & 36.7 & 1.33 & 0.11 & 1.296 \\
\hline S3 & 13.2 & 58.7 & 23.5 & 2.38 & 0.77 & 1.460 \\
\hline S4 & 30.8 & 42.1 & 21.5 & 4.00 & 1.14 & 9.507 \\
\hline S5 & 14.2 & 40.3 & 40.3 & 2.35 & 0.22 & 2.593 \\
\hline S6 & 25.3 & 39.7 & 26.5 & 1.93 & 1.04 & 5.510 \\
\hline S7 & 18.0 & 36.9 & 37.7 & 2.87 & 0.30 & 4.309 \\
\hline S8 & 28.7 & 33.8 & 35.2 & 0.59 & 0.22 & 1.476 \\
\hline S9 & 14.2 & 18.3 & 25.2 & 0.55 & 0.10 & 0.305 \\
\hline S10 & 12.4 & 14.3 & 16.6 & 0.97 & 0.13 & 0.507 \\
\hline S11 & 13.5 & 41.9 & 16.6 & 0.58 & 0.10 & 0.642 \\
\hline S12 & 12.8 & 42.1 & 20.1 & 0.52 & 0.25 & 0.642 \\
\hline S13 & 14.7 & 39.1 & 21.2 & 0.31 & 0.26 & 0.63 \\
\hline S14 & 15.4 & 38.5 & 18.5 & 0.13 & 0.19 & 0.55 \\
\hline S15 & 17.2 & 35.6 & 17.5 & 0.78 & 0.19 & 0.64 \\
\hline S16 & 18.3 & 30.7 & 19.7 & 0.33 & 0.14 & 0.75 \\
\hline S17 & 14.5 & 32.1 & 20.2 & 0.21 & 0.52 & 0.81 \\
\hline S18 & 17.5 & 40.5 & 25.5 & 0.25 & 0.34 & 0.94 \\
\hline S19 & 15.0 & 36.2 & 28.6 & 0.17 & 0.62 & 0.92 \\
\hline S20 & 13.0 & 30.5 & 30.1 & 0.91 & 0.75 & 0.95 \\
\hline S21 & 11.0 & 28.9 & 30.5 & 0.52 & 0.53 & 0.98 \\
\hline S22 & 12.0 & 28.6 & 22.2 & 0.13 & 0.62 & 0.88 \\
\hline $\mathbf{S} 23$ & 16.0 & 25.7 & 25.6 & 0.21 & 0.28 & 0.71 \\
\hline $\mathbf{S 2 4}$ & 15.0 & 35.7 & 33.3 & 0.17 & 0.31 & 0.60 \\
\hline S25 & 20.0 & 35.8 & 31.5 & 0.19 & 0.42 & 0.58 \\
\hline S26 & 21.0 & 36.3 & 29.8 & 0.95 & 0.20 & 0.52 \\
\hline S27 & 20.1 & 30.1 & 28.2 & 0.21 & 0.36 & 0.62 \\
\hline S28 & 19.0 & 29.5 & 25.1 & 0.19 & 0.41 & 0.51 \\
\hline S29 & 18.0 & 28.6 & 25.1 & 0.17 & 0.24 & 0.53 \\
\hline S30 & 16.21 & 27.5 & 20.1 & 0.17 & 0.21 & 0.32 \\
\hline S31 & 15.32 & 32.0 & 18.5 & 0.15 & 0.31 & 0.41 \\
\hline S32 & 13.02 & 31.2 & 15.4 & 0.14 & 0.34 & 1.1 \\
\hline S33 & 14.21 & 26.5 & 17.3 & 0.13 & 0.26 & 1.2 \\
\hline S34 & 16.1 & 27.4 & 22.1 & 0.18 & 0.5 & 0.54 \\
\hline S35 & 17.2 & 29.3 & 21.5 & 0.19 & 0.8 & 0.62 \\
\hline S36 & 18.4 & 30.1 & 23.6 & 1.1 & 1.1 & 1.4 \\
\hline S37 & 19.45 & 37.2 & 21.4 & 1.7 & 1.3 & 1.2 \\
\hline S38 & 16.1 & 34.13 & 28.5 & 2.43 & 2.15 & 1.83 \\
\hline S39 & 19.4 & 36.78 & 26.8 & 2.97 & 1.13 & 1.57 \\
\hline S40 & 20.54 & 36.87 & 26.6 & 2.58 & 1.40 & 1.60 \\
\hline Min. & 11 & 24.6 & 15.4 & 0.13 & 0.1 & 0.305 \\
\hline Max. & 35.95 & 58.7 & 43.6 & 4 & 2.15 & 9.507 \\
\hline Aver. & 23.5 & 40.8 & 29.6 & 2.1 & 1.1 & 4.8 \\
\hline
\end{tabular}

by meteoric water.

\section{Hematite}

Hematite has at wide range of distribution as magnetite and both are present in the first two fractions in the stream sediments samples. It is considered as the major heavy mineral in the host rock samples (Fig.15). These mineral constituents range from $0.01 \%$ to $0.4 \%$ with an average of $0.1 \%$, and represented by histogram (Fig.16). The Semi quantitative analy- ses (EDX) show high iron content with low content of Titaniume, Manganese (Fig.17).

\section{Ilmenite $\left[\mathrm{FeTiO}_{3}\right]$}

The ilmenite grains of the stream sediments may be altered. It concentrated in a relatively the highly magnetic fraction at $0.2 \mathrm{amp}$. It is the most abundant $\mathrm{Fe}$-Ti oxide mineral that occurs in a wide variety of igneous rocks, some metamorphic rocks, and as detritus mineral grains. Ilmenite in the studied stream sedi- 
MINERALOGY AND RADIOACTIVITY STUDIES OF WADI ABU

Table 5a:The weight percentages of the concerned heavy minerals Table 5b:The weight

\begin{tabular}{|c|c|c|c|c|c|c|c|c|c|c|c|c|}
\hline \multirow[t]{2}{*}{$\begin{array}{l}S . \\
\text { No. }\end{array}$} & \multirow[t]{2}{*}{$\begin{array}{l}\text { Gar. } \\
\%\end{array}$} & \multirow[t]{2}{*}{$\begin{array}{l}\text { Rut. } \\
\%\end{array}$} & \multirow[t]{2}{*}{ Tit. \% } & \multirow[t]{2}{*}{$\begin{array}{l}\text { Flu. } \\
\%\end{array}$} & \multirow[t]{2}{*}{$\begin{array}{l}\mathrm{Zr} . \\
\%\end{array}$} & \multirow[t]{2}{*}{$\begin{array}{l}\text { Mz. } \\
\%\end{array}$} & \multirow[t]{2}{*}{$\begin{array}{l}\text { Tho. } \\
\%\end{array}$} & \multirow{2}{*}{$\begin{array}{l}\text { Amph. } \\
\& \\
\text { Pyr.\% } \\
\end{array}$} & \multicolumn{3}{|c|}{$\begin{array}{l}\text { in the studied } \\
\text { sediment samples }\end{array}$} & \multirow{2}{*}{$\begin{array}{c}\text { strean } \\
\mathrm{Hm} .\end{array}$} \\
\hline & & & & & & & & & $\overline{\text { S. No. }}$ & Mag. & Ilm. & \\
\hline 1 & 0.1 & 0.3 & 0.2 & 0.01 & 0.1 & 0.05 & 0.01 & 2.04 & $\overline{1}$ & 1.5 & 0.5 & 0.2 \\
\hline 2 & 0.3 & 0.5 & 0.1 & 0.01 & 0.3 & 0.07 & 0.02 & 3.11 & 2 & 1.8 & 0.8 & 0.2 \\
\hline 3 & 0.2 & 0.6 & 0.3 & 0.01 & 0.5 & 0.03 & 0.01 & 1.96 & 3 & 1.4 & 0.6 & 0.1 \\
\hline 4 & 0.4 & 0.8 & 0.4 & 0.03 & 0.6 & 0.06 & 0.03 & 1.51 & 4 & 2 & 0.9 & 0.3 \\
\hline 5 & 0.2 & 0.5 & 0.3 & 0.03 & 0.4 & 0.01 & 0.01 & 3.69 & 5 & 1.2 & 0.3 & 0.1 \\
\hline 6 & 0.3 & 0.7 & 0.2 & 0.02 & 0.6 & 0.01 & 0.01 & 3.78 & 6 & 1.1 & 0.2 & 0.2 \\
\hline 7 & 0.1 & 0.9 & 0.3 & 0.04 & 0.7 & 0.02 & 0.02 & 2.56 & 7 & 1.3 & 0.3 & 0.2 \\
\hline 8 & 0.2 & 1.1 & 0.5 & 0.02 & 0.9 & 0.04 & 0.03 & 3.63 & 8 & 2 & 0.9 & 0.3 \\
\hline 9 & 0.06 & 0.3 & 0.4 & 0.03 & 0.1 & 0.01 & 0.001 & 2.33 & 9 & 1.3 & 0.2 & 0.1 \\
\hline 10 & 0.1 & 0.2 & 0.3 & 0.01 & 0.2 & 0.01 & 0.001 & 1.9 & 10 & 1.1 & 0.3 & 0.1 \\
\hline 11 & 0.3 & 0.4 & 0.2 & 0 & 0.5 & 0.04 & 0.03 & 1.73 & 11 & 1.6 & 0.1 & 0.2 \\
\hline 12 & 0.1 & 0.2 & 0.1 & 0 & 0.3 & 0.001 & 0.001 & 2.2 & 12 & 1.7 & 0.4 & 0.3 \\
\hline 13 & 0.3 & 0.3 & 0.22 & 0 & 0.4 & 0.001 & 0 & 3.1 & 13 & 1.0 & 0.5 & 0.4 \\
\hline 14 & 0.04 & 0.25 & 0.2 & 0 & 0.2 & 0.01 & 0 & 3.1 & 14 & 2.1 & 0.2 & 0.1 \\
\hline 15 & 0.03 & 0.4 & 0.1 & 0 & 0.1 & 0 & 0 & 2.9 & 15 & 1 & 0.1 & 0.03 \\
\hline 16 & 0.01 & 0.2 & 0.02 & 0 & 0.08 & 0 & 0 & 2.7 & 16 & 0.8 & 0.1 & 0.02 \\
\hline 17 & 0.02 & 0.21 & 0.03 & 0 & 0.08 & 0 & 0 & 2.5 & 17 & 0.7 & 0.2 & 0.01 \\
\hline 18 & 0.02 & 0.18 & 0.01 & 0 & 0.05 & 0.001 & 0 & 2.8 & 18 & 0.9 & 0.14 & 0.03 \\
\hline 19 & 0.01 & 0.15 & 0.01 & 0 & 0.05 & 0.001 & 0 & 1.5 & 19 & 0.7 & 0.12 & 0.03 \\
\hline 20 & 0.01 & 0.12 & 0.01 & 0 & 0.04 & 0.001 & 0 & 1.4 & 20 & 0.6 & 0.1 & 0.01 \\
\hline 21 & 0.01 & 0.10 & 0.01 & 0 & 0.03 & 0.001 & 0 & 2.1 & 21 & 0.8 & 0.1 & 0.02 \\
\hline 22 & 0.03 & 0.2 & 0.01 & 0 & 0.02 & 0.001 & 0 & 2.2 & 22 & 0.4 & 0.15 & 0.03 \\
\hline 23 & 0.04 & 0.22 & 0.02 & 0 & 0.05 & 0.001 & 0 & 3.1 & 23 & 0.2 & 0.2 & 0.01 \\
\hline 24 & 0.04 & 0.3 & 0.03 & 0 & 0.07 & 0 & 0 & 3.2 & 24 & 0.15 & 0.3 & 0.02 \\
\hline 25 & 0.03 & 0.2 & 0.02 & 0 & 0.02 & 0 & 0 & 3.4 & 25 & 0.1 & 0.13 & 0.01 \\
\hline 26 & 0.01 & 0.1 & 0.02 & 0 & 0.01 & 0 & 0 & 3.5 & 26 & 0.2 & 0.14 & 0.03 \\
\hline 27 & 0.05 & 0.1 & 0.1 & 0 & 0.2 & 0 & 0 & 2.2 & 27 & 0.1 & 0.2 & 0.01 \\
\hline 28 & 0.04 & 0.21 & 0.1 & 0 & 0.06 & 0 & 0 & 2.3 & 28 & 0.2 & 0.21 & 0.02 \\
\hline 29 & 0.05 & 0.1 & 0.1 & 0 & 0.04 & 0 & 0 & 2.8 & 29 & 0.4 & 0.5 & 0.04 \\
\hline 30 & 0.02 & 0.2 & 0.1 & 0 & 0.06 & 0 & 0 & 3.0 & 30 & 0.8 & 0.1 & 0.1 \\
\hline 31 & 0.01 & 0.1 & 0.2 & 0 & 0.04 & 0 & 0 & 3.1 & 31 & 0.5 & 0.1 & 0.02 \\
\hline 32 & 0.01 & 0.1 & 0.1 & 0 & 0.03 & 0 & 0 & 3.2 & 32 & 0.4 & 0.08 & 0.01 \\
\hline 33 & 0.04 & 0.2 & 0.3 & 0 & 0.02 & 0 & 0 & 3.5 & 33 & 0.5 & 0.2 & 0.02 \\
\hline 34 & 0.07 & 0.18 & 0.3 & 0 & 0.01 & 0 & 0 & 0.1 & 34 & 1 & 0.07 & 0.04 \\
\hline 35 & 0.1 & 0.3 & 0.5 & 0.1 & 0.05 & 0.001 & 0.001 & 0.1 & 35 & 1.2 & 0.3 & 0.07 \\
\hline 36 & 0.2 & 0.4 & 0.6 & 0.02 & 0.07 & 0.001 & 0.001 & 0.1 & 36 & 1.5 & 0.2 & 0.06 \\
\hline 37 & 0.4 & 0.5 & 0.6 & 0.02 & 0.06 & 0.001 & 0.001 & 0.1 & 37 & 1.9 & 0.3 & 0.1 \\
\hline 38 & 0.3 & 0.5 & 0.7 & 0.02 & 0.1 & 0.001 & 0.001 & 0.1 & 38 & 2.2 & 0.3 & 0.1 \\
\hline 39 & 0.5 & 0.6 & 0.7 & 0.01 & 0.1 & 0.001 & 0.001 & 0.1 & 39 & 2.1 & 0.4 & 0.2 \\
\hline 40 & 0.5 & 0.6 & 0.7 & 0.01 & 0.1 & 0.001 & 0.001 & 0.1 & 40 & 2.3 & 0.5 & 0.3 \\
\hline Min. & 0.01 & 0.1 & 0.01 & 0.01 & 0.01 & 0.001 & 0.001 & 0.11 & Min. & 0.1 & 0.07 & 0.01 \\
\hline Max. & 0.5 & 1.1 & 0.7 & 0.03 & 0.9 & 0.07 & 0.03 & 3.78 & Max. & 2.3 & 0.9 & 0.4 \\
\hline Aver. & 0.131 & 0.19 & 0.228 & 0.008 & 0.18 & 0.001 & 0.001 & 2.2185 & Aver. & 1.069 & 0.29 & 0.104 \\
\hline
\end{tabular}




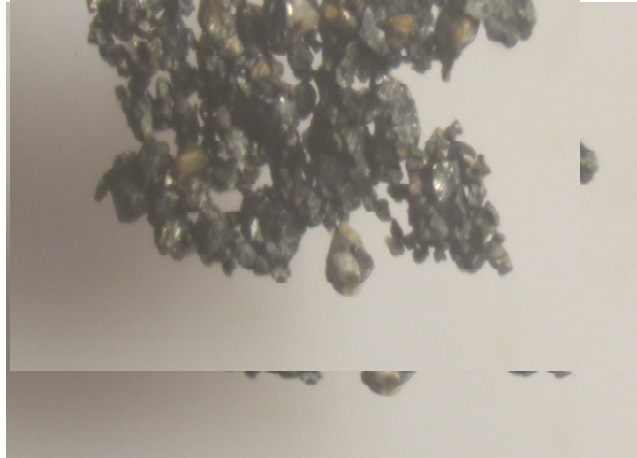

Fig.13:Photomicrograph of magnetite

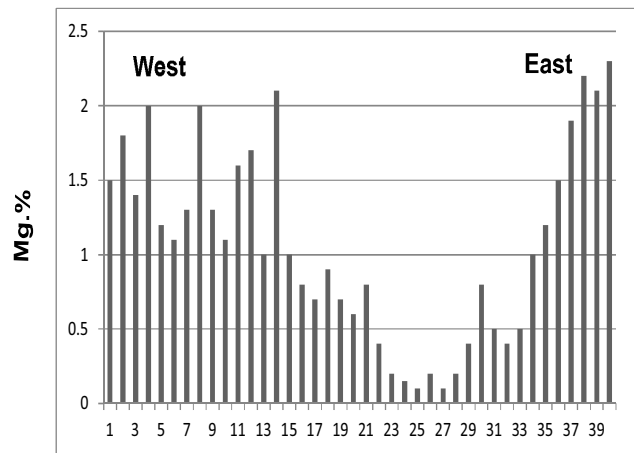

Fig.14:Histogram distribution of magnetite

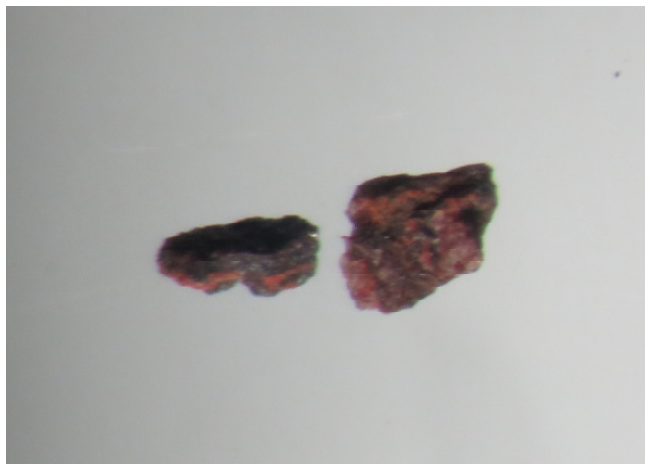

Fig.15:Photomicrograph of hematite
EL AZAB

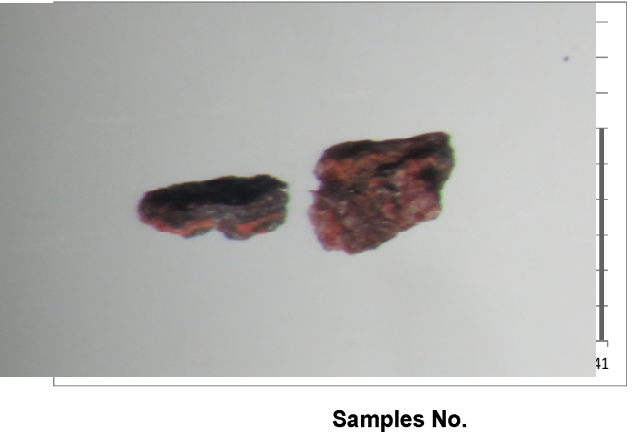

Fig.16:Histogram distribution of hematite

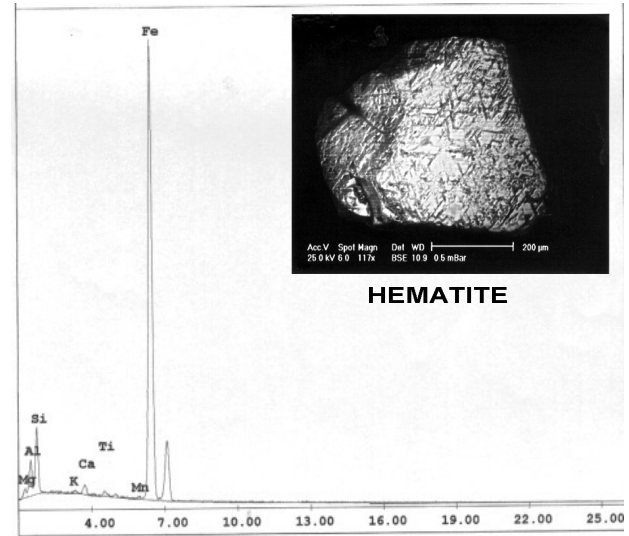

Fig.17: (EDX) ESEM hematite analysis

ments occurs as irregular, tabular or massive to subrounded, angular grains (Fig. 18). These grains exhibit black to brownish black colors and submetallic to metallic luster. The brownish tint of some ilmenite grains may be due to the partial alteration of these grains. These mineral constituents range from $0.07 \%$ to 0.9 $\%$ with an average of $0.29 \%$, and represented by histogram (Fig.19).

\section{Garnet}

The minerals of garnet group characterize some metamorphic rocks and in some igneous rock types, and can be noticed generally as detritus grains in sediments. It exhibits dif- 


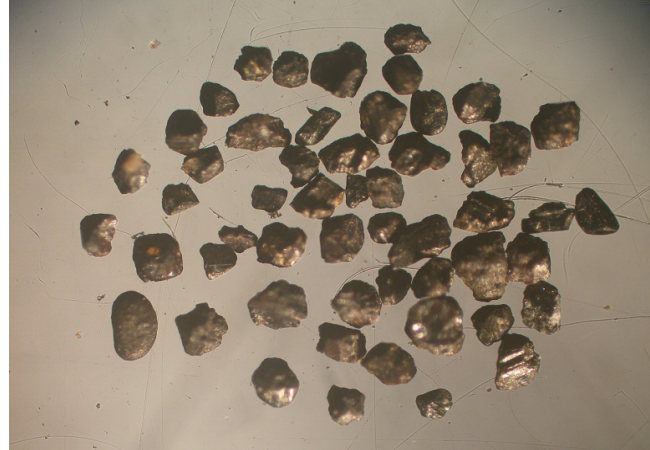

Fig.18:Photomicrograph of ilmenite

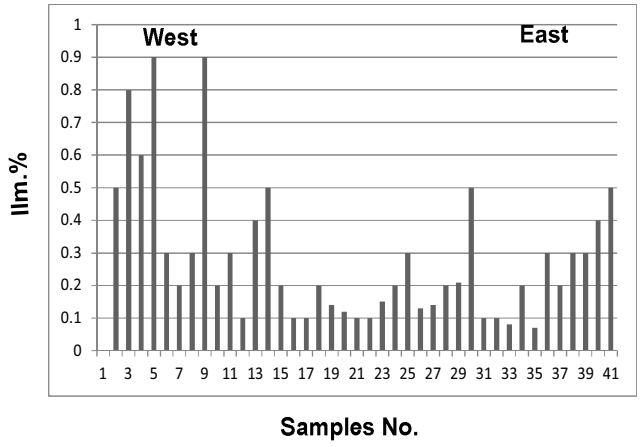

Fig.19 Histogram distribution of ilmenite

ferent colors ranging from pale pink to dark brown with vitreous luster. Sometimes, garnet grains appear to be cloudy due to staining or inclusions (Fig.20). The alamandine type is the common garnet mineral in the studied samples, probably due to the effect of contact or regional metamorphism. These mineral constituents range from $0.01 \%$ to $0.5 \%$ with an average of $0.13 \%$, and represented by histogram (Fig.21). The garnet in the studied stream sediments was confirmed either by ESEM (Fig.22).

\section{TITANIUM MINERALS}

\section{Rutile $\left[\mathrm{TiO}_{2}\right]$}

It is the preferred mineral for the production of titanium dioxide. Rutile mineral grains

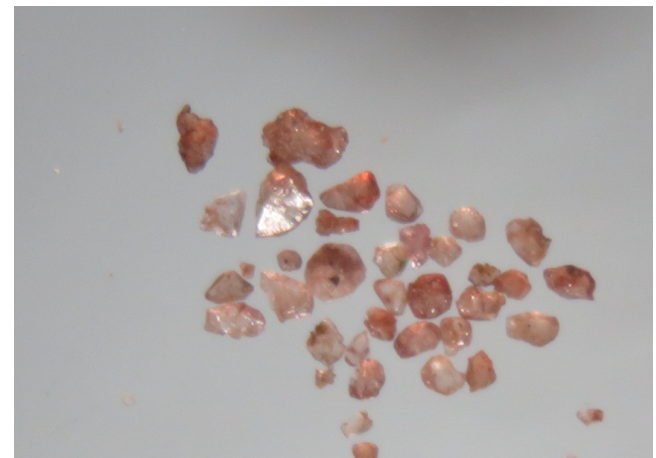

Fig.20:Photomicrograph of garnet

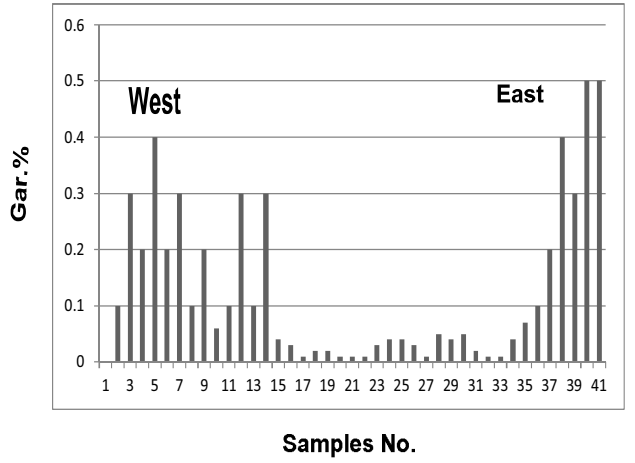

Fig.21:Histogram distribution of garnet

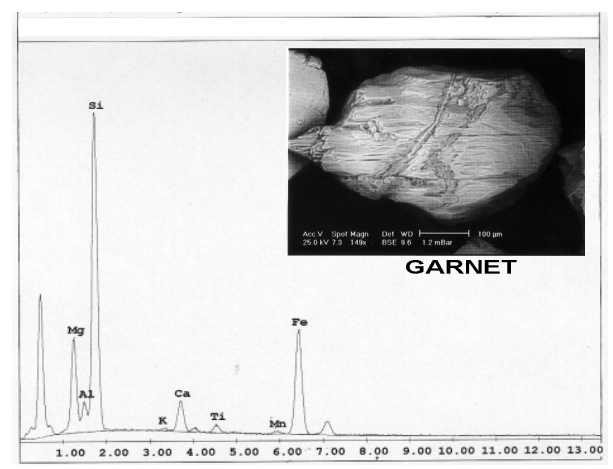

Fig.22: ESEM garnet analysis 
are commonly prismatic, elongated, tabular and massive granular in shape. The common colors of rutile are reddish brown grading into the red (Fig.23) and black with adamantine luster. These mineral constituents ranged from $0.1 \%$ to $1.1 \%$ with an average of $0.188 \%$, and represented by histogram (Fig.24).

\section{Titanite (Sphene) $\left[\mathrm{CaTiSiO}_{5}\right]$}

It is widespread in acidic and intermediate igneous rocks, and in several metamorphic rocks as accessory phase. It exhibits transparent to translucent yellow to yellowish brown colours (Fig.25). Titanite mineral grains are subhedral to anhedral grains of adamantine luster and imperfect cleavage. The presence of titanite in the studied sediments was confirmed either by ESEM (Fig.26), and X-ray diffraction (Table 6). These mineral constituents ranged from $0.01 \%$ to $0.7 \%$ with an average of $0.23 \%$, and represented by the histogram (Fig.27).

\section{Fluorites}

Fluorite is present in the stream sediments as coarse grains. It is whitish or pale yellow in color and has irregular wedge shape (Fig.28). Fluorite may have been originated from the granitic magma during the differentiation, or later at the deuteric stage forming the coarser fluorite sizes. These mineral con-

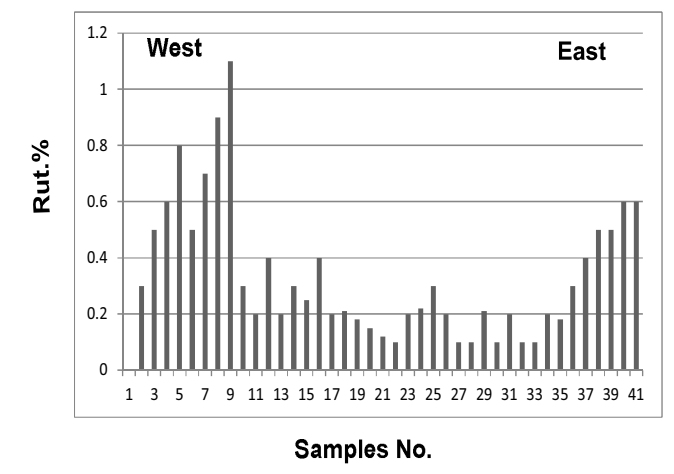

Fig.24:Histogram distribution of rutile

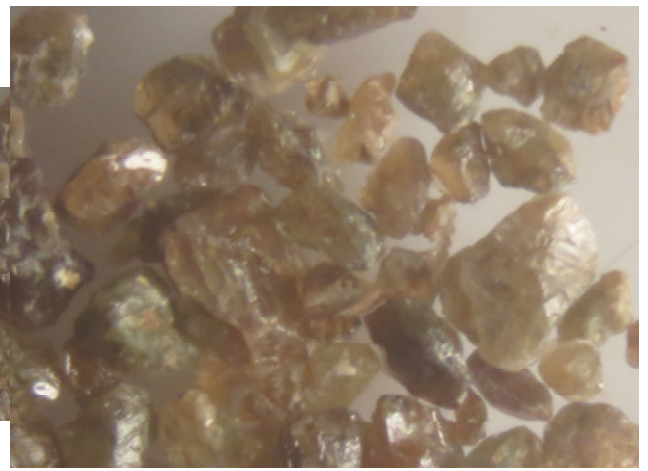

Fig.25:Photomicrograph of titanite
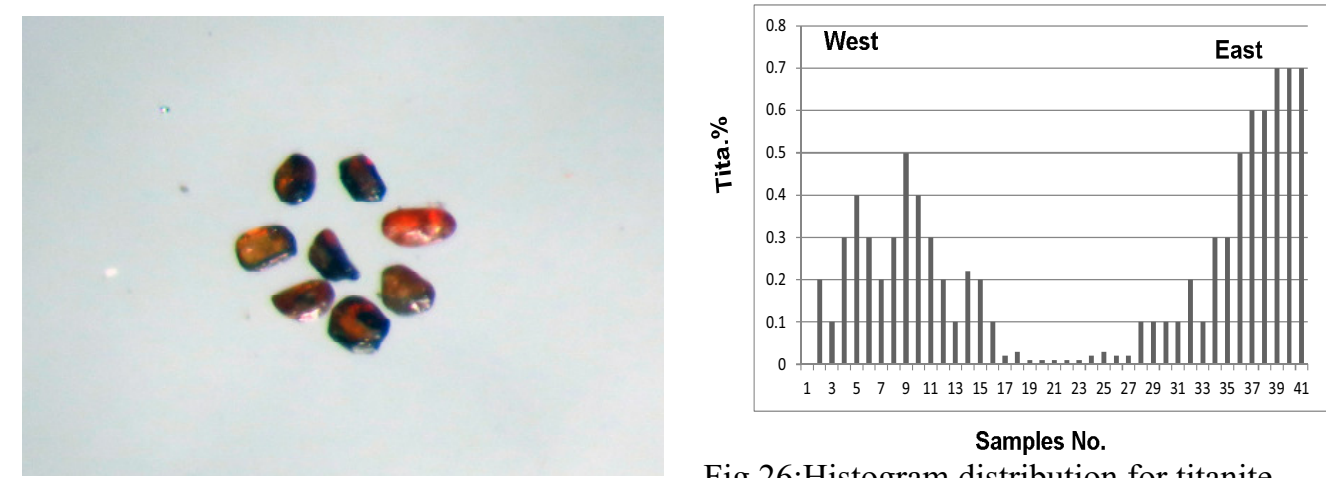

Fig.23:Photomicrograph of rutile

Fig.26:Histogram distribution for titanite 
Table 6:X-ray diffraction data of titanite of Wadi Abu Hamur-Safaga area

\begin{tabular}{lrlr}
\hline $\begin{array}{l}\text { Analysed } \\
\text { Sample }\end{array}$ & & $\begin{array}{l}\text { Titanite ASTM card } \\
(11-446)\end{array}$ \\
\hline dA & I/I $_{\text {o }}$ & dA & I/I \\
7.22 & 6 & & \\
4.95 & 23 & 4.93 & 30 \\
3.24 & 100 & 3.233 & 100 \\
3.00 & 97 & 2.989 & 90 \\
2.61 & 67 & & \\
2.59 & 55 & 2.595 & 90 \\
2.29 & 19 & 2.273 & 30 \\
2.07 & 27 & 2.058 & 40 \\
1.65 & 24 & 1.643 & 40 \\
1.50 & 17 & 1.494 & 4 \\
\hline
\end{tabular}

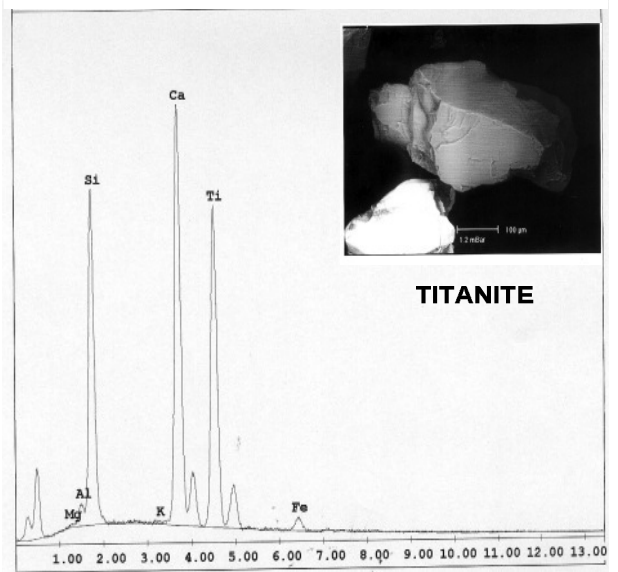

Fig.27:ESEM titanite analysis

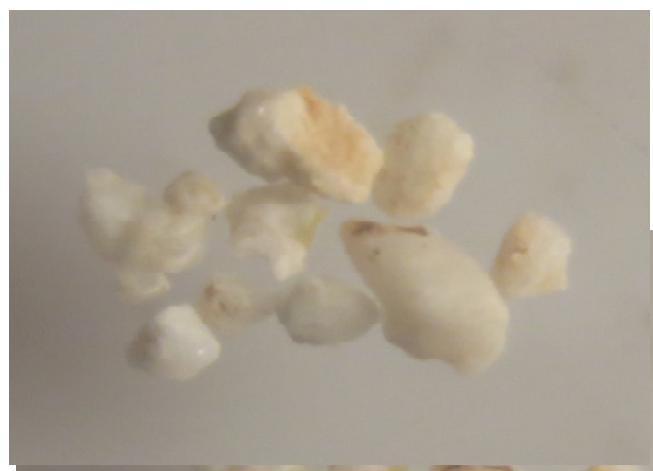

Fig.28:Photomicrograph of fluorite stituents ranged from $0.01 \%$ to $0.03 \%$ with an average of $0.0075 \%$, and represented by the histogram (Fig.29).

\section{RADIOACTIVE MINERALS}

\section{Zircon $\left[\mathrm{ZrSiO}_{4}\right]$}

Zircon is a remarkable mineral due to its ubiquitous occurrence in crustal igneous, metamorphic and sedimentary rocks, and in even mantle xenoliths, lunar rocks, meteorites and tektite (Speer, 1980). It occurs as an euhedral to subhedral grains, Prismatic with bi-pyramidal termination (Fig.30a), and two bi-pyramidal (Fig.30b). It is exhibiting brownish yellow colours of adamantine luster. These mineral constituents range from $0.01 \%$ to $0.9 \%$ with an average $0.184 \%$, and represented by histogram (Fig.31). ESEM data (EDX) indicate that zircon consists mainly of $\mathrm{ZrO}_{2}$ and $\mathrm{SiO}_{2}$ with trace amounts of $\mathrm{Ca}, \mathrm{Hf}, \mathrm{Fe}$ and $\mathrm{Al}$ (Fig.32). The $\mathrm{Zr} / \mathrm{Hf}$ ratio is a principle indicator of magmatic differentiation. The average $\mathrm{Zr} / \mathrm{Hf}$ of zircon from granitoid rocks is 37.3, while this ratio reaches to 49.6 for volcanic rocks, 55.7 for basic rocks and 67 for ultrabasic rocks (Lyakhvich and Vishneveskiy, 1990). For the studied zircon, $\mathrm{Zr} / \mathrm{Hf}$ ranges from 31.15 to 41.78 , indicating that they derived from granitoid rocks.

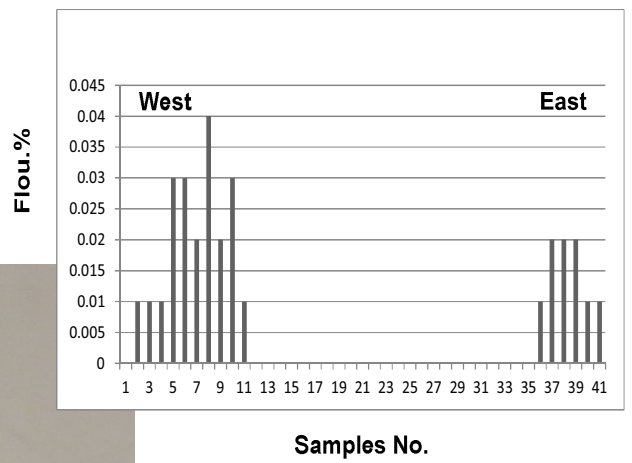

Fig.29: Histogram distribution of fluorite 


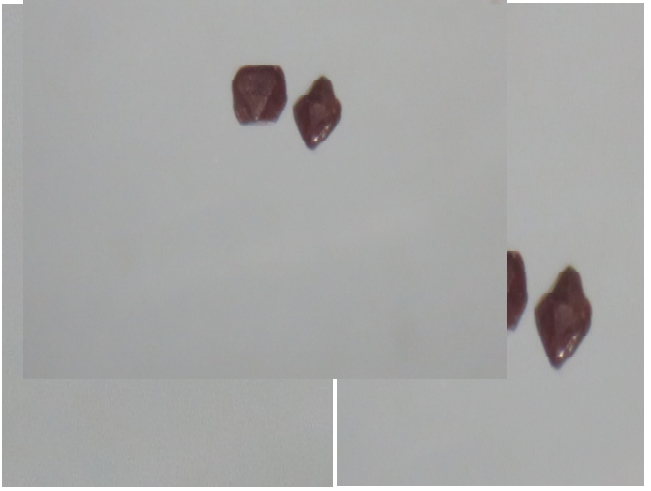

Fig.30 a\&b: Photomicrograph of zircon

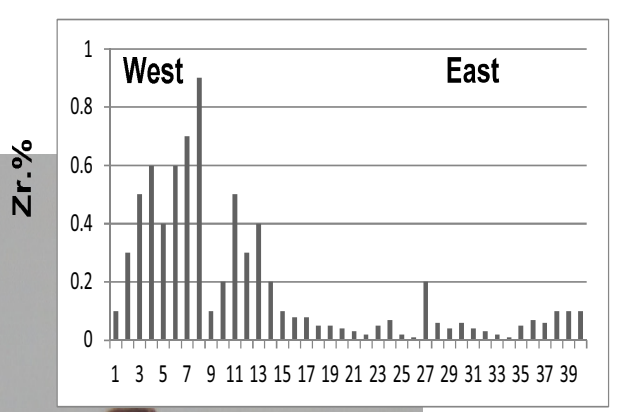

Samples No.

Fig.31:Histogram distribution for zircon

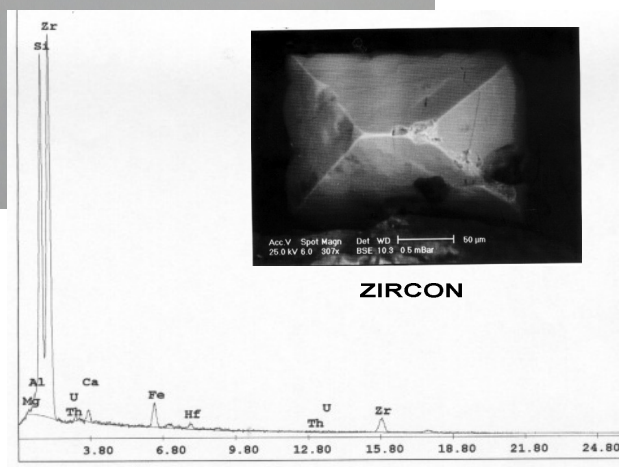

Fig.32:ESEM zircon analysis

\section{Monazite $\left[\mathrm{CeLaPO}_{4}\right]$}

It is one of the most important nuclear minerals, being a major host for REEs and actinides Th and U (Hinton and Paterson 1994, Bea et al., 1994 and Bea 1996). Monazite in the studied samples is rare in the heavy minerals of these samples. It forms tabular and broken crystals. Most of these grains are characterized by pitted surfaces. It is pale yellow, honey yellow, greenish yellow and reddish yellow colour grains. These mineral constituents ranged from $0.001 \%$ to $0.07 \%$ with an average of $0.001 \%$ and represented by the histogram (Fig.33 ). The EDX data (Fig.34).

\section{Thorite $\left[\mathrm{ThSiO}_{4}\right]$}

It occurs widely in the form of accessory minerals, which belong to the most important basic commercial minerals of thorium. It occurs as brownish black to black opaque grains of greasy luster (Fig.35). Most of thorite mineral grains are subhedral to anhedral corroded and cracked. These mineral constituents range from $0.001 \%$ to $0.03 \%$ with an average 0.001 $\%$, and represented by histogram (Fig. 36).

They are strongly metamictized, as determined by X-ray diffraction. In nature, thorite, generally, occurs in metamict state, amorphous to X-ray and electron diffraction, even though,

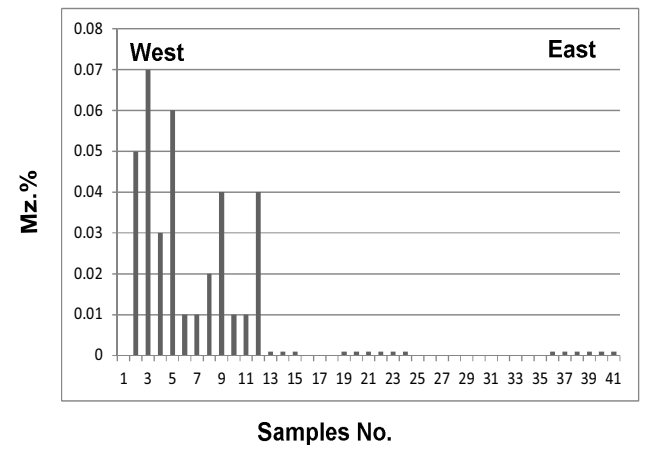

Fig.33: Histogram distribution of monazite 


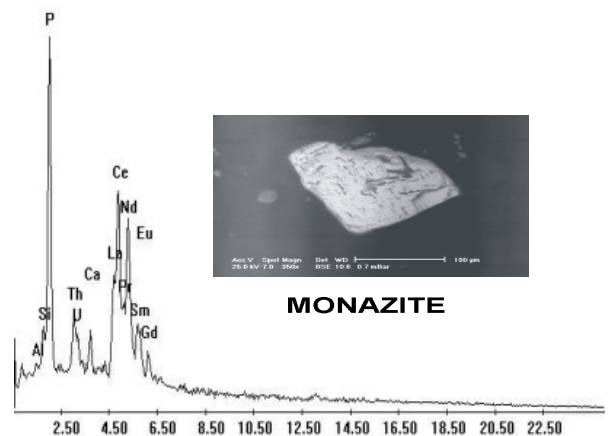

Fig.34:(EDX) ESEM monazite

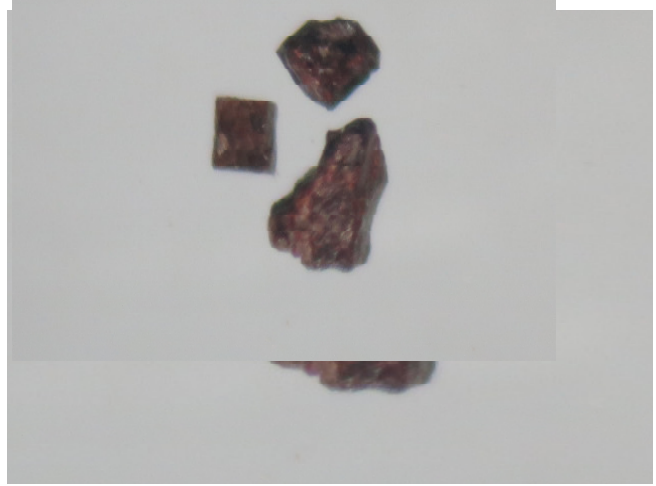

Fig.35:Photomicrograph of thorite

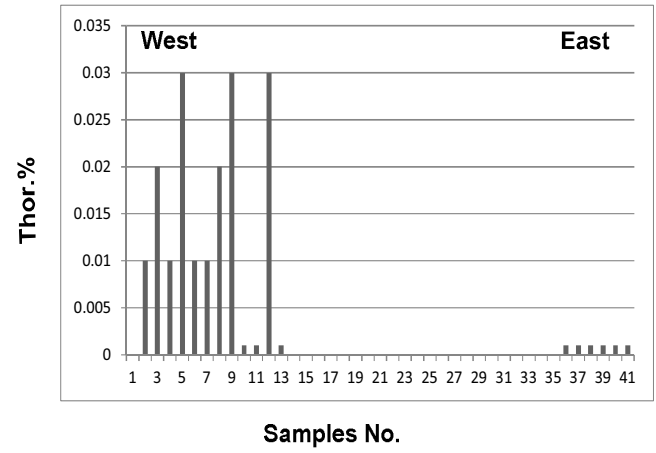

Fig.36:Histogram distribution of thorite they may have crystal faces (Palache et al. 1944, Pabst 1952, Ewing and Haaker 1980). Thorite was annealed at $1100^{\circ} \mathrm{C}$ for approximately four hours preceding identification by XRD. The obtained data (Table 7) reveal the presence of thorite peaks (ASTM card 11-419) in addition to hematite peaks (ASTM card 13534). The presence of hematite may be in the form of thin films coating thorite grains or as individual hematite grains. The ESEM analysis shows that thorite consists mainly of $\mathrm{ThO}_{2}$ and $\mathrm{SiO}_{2}$. Minor and trace elements include $\mathrm{Y}$, U, Ca, Fe and REE (Fig. 37).

\section{Amphiboles and Pyroxenes}

These minerals consists of amphiboles, pyroxene, biotite, muscovite and epidote, and detected in the stream sediments. These minerals may have originated from igneous rocks. These minerals are characterized by coarse size detrital particles, black, green to pale green colour (Fig.38) and has medium to high magnetic success-ability. These mineral constituents range from $0.1 \%$ to $3.78 \%$ with an average of $2.22 \%$, and represented by histogram (Fig.39).

\section{RADIOMETRIC STUDY}

The collected samples has been subjected to radiometric analyses to the studied area determine variations in $\mathrm{eU}, \mathrm{eTh}, \mathrm{Ra}$ and $\mathrm{K} \%$. The obtained results from the radiometric measurements of the studied stream sediments are listed in Table 8, and calculate the ratios of $\mathrm{eU} / \mathrm{eTh}$ and $\mathrm{eU} / \mathrm{Ra}$. Draw the histograms distribution for these elements and ratios (Figs. $40 \& 41)$.

The examined stream sediments of Wadi Abu Hamur-Safaga are characterized by radiometrically (low to moderately) concentrations of eU and eTh. The radiometrically elemental concentration of eU range between 1 and $4 \mathrm{ppm}$ with an average of $1.76 \mathrm{ppm}$, while eTh is between 2 and 29ppm with an average of $10.75 \mathrm{ppm}$. The average Ra content for these sediments is $2.89 \mathrm{ppm}$, ranging between 
Table 7:X-ray diffraction data of the annealed thorite from the studied stream sediments

\begin{tabular}{|c|c|c|c|c|c|}
\hline \multicolumn{2}{|c|}{ Analyzed Sample } & \multicolumn{2}{|c|}{ Thorite } & \multicolumn{2}{|c|}{ Hematite } \\
\hline $\mathbf{d A}$ & I/IO & $\mathbf{d A}$ & I/IO & $\mathbf{d A}$ & I/IO \\
\hline 4.67 & 59 & 4.72 & 85 & & \\
\hline 3.54 & 100 & 3.55 & 100 & 3.66 & 25 \\
\hline 2.82 & 21 & 2.842 & 45 & & \\
\hline 2.70 & 32 & & & 2.69 & 100 \\
\hline 2.64 & 46 & 2.676 & 75 & & \\
\hline 2.52 & 21 & 2.516 & 30 & 2.51 & 50 \\
\hline 2.34 & 3 & 2.361 & 5 & & \\
\hline 2.20 & 22 & 2.222 & 30 & 2.201 & 30 \\
\hline 2.07 & 2 & & & 2.07 & 2 \\
\hline 1.99 & 9 & 2.019 & 20 & & \\
\hline 1.87 & 15 & 1.885 & 30 & & \\
\hline 1.82 & 28 & 1.834 & 65 & 1.838 & 40 \\
\hline 1.77 & 10 & 1.782 & 20 & & \\
\hline 1.69 & 12 & & & 1.69 & 60 \\
\hline 1.65 & 8 & 1.667 & 10 & 1.634 & 4 \\
\hline 1.48 & 5 & 1.484 & 20 & 1.484 & 35 \\
\hline 1.43 & 4 & 1.444 & 15 & 1.453 & 35 \\
\hline
\end{tabular}

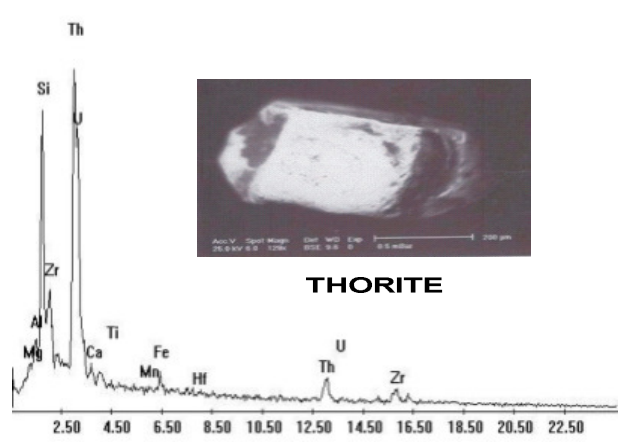

Fig.37: (EDX) ESEM thorite

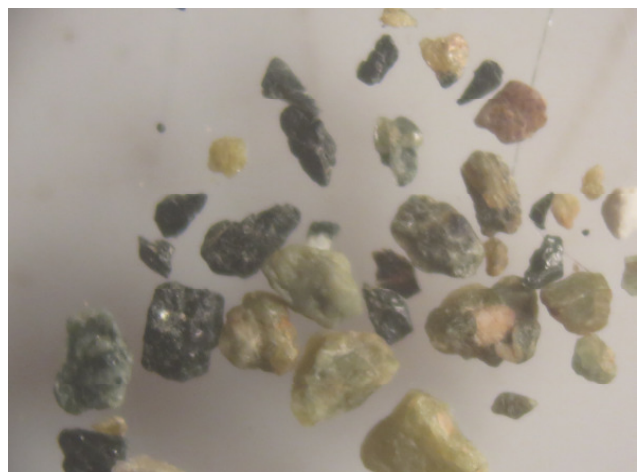

Fig.38:Photomicrograph of amphiboles and pyroxenes

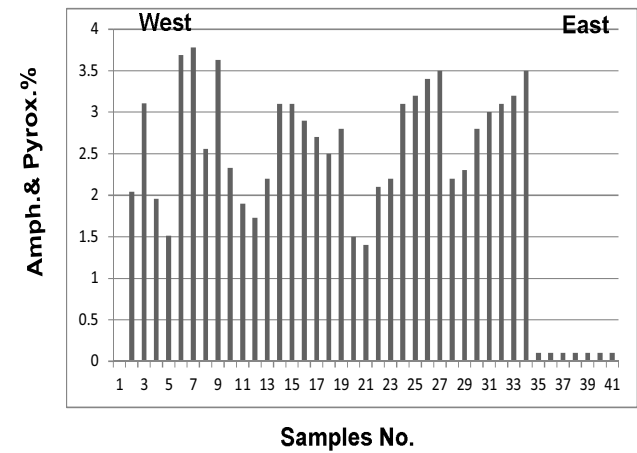

Fig.39:Histogram distribution of amphiboles and pyroxenes

1 and $5 \mathrm{ppm}$. The average content of $\mathrm{K} \%$ $1.16 \%$, ranging between 0.1 and 1.56 .

Ivanovich (1994) concluded that a relatively constant $\mathrm{Th} / \mathrm{U}$ mass ratio of around 3.5 is found in most natural systems. The average of the corresponding value (eTh/eU ratio) for the sediments of Wadi Abu Hamur-Safaga is 5.48 varying between 1.33 and 12.5 which indicate that there is a significant fractionation during weathering of these sediments causing the depletion of $\mathrm{U}$. 
Table 8: eU, eTh, Ra (ppm) and K (\%) content of the Wadi Abu Hamur-Safaga stream sediments

\begin{tabular}{|c|c|c|c|c|c|c|}
\hline S. No & $\begin{array}{r}\mathrm{eU} \\
(\mathbf{p p m})\end{array}$ & $\begin{array}{r}\text { eTh } \\
(\mathbf{p p m})\end{array}$ & $\begin{array}{r}\mathbf{R a} \\
\text { (ppm) }\end{array}$ & $\begin{array}{l}\mathbf{K} \\
(\%)\end{array}$ & eTh/eU & $\begin{array}{r}\text { ARs } \\
(\mathrm{eU} / \mathrm{Ra}) \\
\end{array}$ \\
\hline$\overline{\text { S1 }}$ & 2 & $\mathbf{1 0}$ & 1 & 1.48 & 5 & $\overline{2}$ \\
\hline S2 & $\mathbf{1}$ & 18 & 2 & 1.56 & 18 & 0 \\
\hline S3 & 3 & 20 & 3 & 1.12 & 6.7 & $\mathbf{1}$ \\
\hline S4 & 4 & 16 & 2 & 1.05 & 4 & 2 \\
\hline S5 & 4 & 17 & 3 & 1.07 & 4.25 & 1 \\
\hline S6 & 2 & 24 & 4 & 1.01 & 12 & 0 \\
\hline S7 & 3 & 28 & 4 & 1.18 & 9.33 & 0 \\
\hline S8 & 4 & 23 & 4 & 0.92 & 5.75 & 1 \\
\hline S9 & 2 & 10 & 3 & 1.04 & 5 & 0 \\
\hline S10 & 1 & 9 & 3 & 1.27 & 9 & 0 \\
\hline S11 & 1 & 8 & 2 & 0.92 & 8 & 0 \\
\hline S12 & 1 & 7 & $\mathbf{1}$ & 1.48 & 7 & $\mathbf{1}$ \\
\hline S13 & 1 & 6 & 2 & 1.56 & 6 & 0 \\
\hline S14 & 1 & 7 & 3 & 1.12 & 7 & 0 \\
\hline S15 & 1 & 5 & 2 & 1.05 & 5 & 0 \\
\hline S16 & 1 & 4 & 3 & 1.07 & 4 & 0 \\
\hline S17 & 1 & 6 & 4 & 1.01 & 6 & 0 \\
\hline S18 & 1 & 3 & 4 & 1.18 & 3 & 0 \\
\hline S19 & 1 & 5 & 4 & 0.92 & 5 & 0 \\
\hline S20 & 1 & 4 & 3 & 1.04 & 4 & $\mathbf{0}$ \\
\hline S21 & 1 & 3 & 3 & 1.27 & 3 & 0 \\
\hline S22 & 1 & 2 & 2 & 0.92 & 2 & 0 \\
\hline $\mathbf{S 2 3}$ & 1 & 2 & 2 & 0.1 & 2 & 0 \\
\hline S24 & 1 & 2 & 1 & 1.48 & 2 & 1 \\
\hline S25 & 1 & 2 & 2 & 1.56 & 2 & 0 \\
\hline S26 & 1 & 3 & 3 & 1.12 & 3 & o \\
\hline S27 & 1 & 3 & 2 & 1.05 & 3 & 0 \\
\hline S28 & 1 & 4 & 3 & 1.07 & 4 & 0 \\
\hline S29 & 1.5 & 5 & 4 & 1.01 & 1.33 & 0 \\
\hline S30 & 1 & 6 & 4 & 1.18 & 6 & 0 \\
\hline S31 & 2 & 5 & 4 & 0.92 & 2.5 & 0 \\
\hline S32 & 2 & 7 & 3 & 1.04 & 3.5 & 0 \\
\hline S33 & 3 & 8 & 3 & 1.27 & 2.7 & 1 \\
\hline S34 & 2 & 15 & 2 & 0.92 & 7.5 & 1 \\
\hline S35 & 2 & 18 & 3 & 1.1 & 9 & 0 \\
\hline S36 & 2 & 16 & 4 & 1.5 & 8 & o \\
\hline S37 & 3 & 21 & 5 & 1.4 & 7 & 0 \\
\hline S38 & 3 & 24 & 3 & 1.3 & 8 & 1 \\
\hline S39 & 2 & 25 & 5 & 1.5 & 12.5 & 0 \\
\hline S40 & 3 & 29 & 4 & 1.5 & 9.7 & 0 \\
\hline Aver. & 1.76 & 10.75 & 2.98 & 1.16 & 5.48 & 0 \\
\hline Min. & 1 & 2 & 1 & 0.1 & 1.33 & 0 \\
\hline Max. & 4 & 29 & 5 & 1.56 & 12.5 & 2 \\
\hline
\end{tabular}



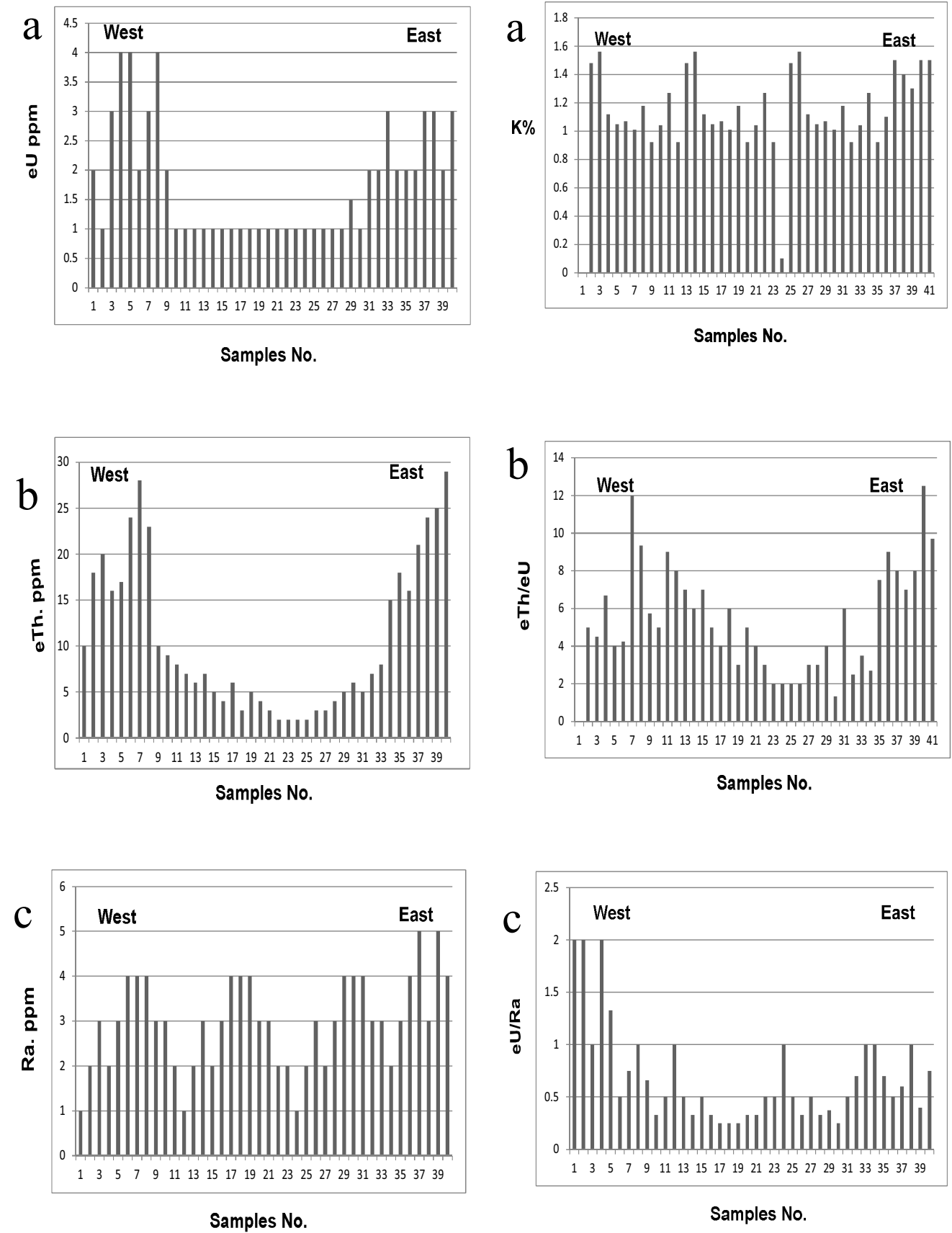

Fig.40 a,b\&c:Histograms distribution of equivalent uranium, thorium, and Ra ppm

Fig.41_a,b\&c: Histograms distribution of $\mathrm{K} \%$, $\mathrm{eTh} / \mathrm{eU}$, and eU/Ra 
The main factors controlling the distribution of radioelements in sediments are the geomorphological features of the basin of deposition, radioelements content of the source rocks, grain size of these sediments, the alkalinity of the surface groundwater, and to a lesser extent effect of the organic matter. ${ }^{238} \mathrm{U} /{ }^{226} \mathrm{Ra}$ activity ratios (ARs) can be used to ascertain equilibrium within the same decay series (Navas et al., 2002). If secular equilibrium prevails in the ${ }^{238} \mathrm{U}$ chain, ARs of ${ }^{238} \mathrm{U} /{ }^{226} \mathrm{U}$ will be approximately 1 , ARs values other than 1 indicate disequilibrium. The ARs for the studied stream sediments of Wadi Abu Hamur-Safaga alternate lower and higher than 1 , which indicate a state of disequilibrium in these sediments.

\section{eU Versus eTh Variation Diagram}

The relation between $U$ and Th may indicate the enrichment or depletion of $U$ because $\mathrm{Th}$ is chemically stable. The eU against eTh variation diagram for the studied samples is shown on Figure 42 , which indicates strong positive relationships between the two elements. This result explains the low alteration processes affecting these samples, and also indicates that magmatic processes played an important role in the uranium enrichment of these granites which represent the source of these sediments.

\section{eU Versus Zr Variation Diagram}

The eU versus $\mathrm{Zr}$ variation diagram shows strong positive correlation in the studied samples (Fig.43). The uranium and zirconium enrichment in the studied samples, supports the concept that $U$ was trapped in the accessory minerals as zircon and the uranium is magmatically.

\section{CONCLUSIONS}

This study of economic minerals in the stream sediments of wadi Abu Hamur-wadi Safaga which has long $30 \mathrm{~km}$ and width reach to $50 \mathrm{~m}$. The area covered by igneous and met-

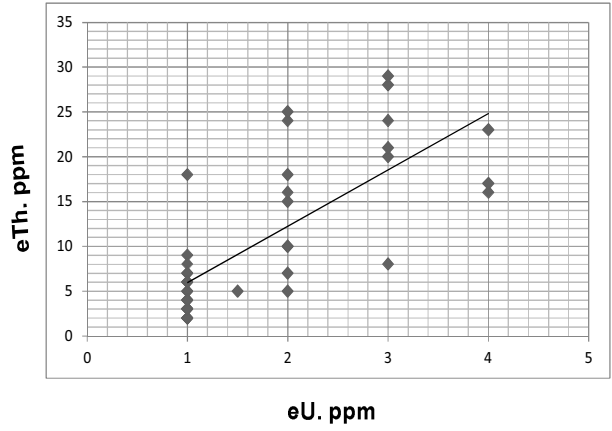

Fig.42:Direct relationship between equivalent uranium and equivalent thorium

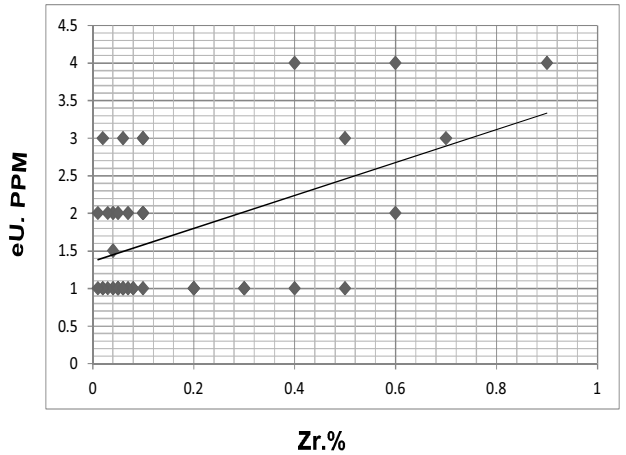

Fig.43:Direct relationship between eU and concentration of $\mathrm{Zr}$ minerals

amorphic rocks represented by Metagabbro, Metavolcanic, Older Granite, Dokhan Volcanics, Hammamat Sediments and Younger Granite.

The area affected by different faults and represented by strike-slip faults of NW trends are right-lateral, while those of E-W, NE, and NNE trends are left-lateral faults. The normal faults are only preserved on a minor scale along these strike-slip faults represented by nearly vertical slickensides that indicate to substantial vertical displacement.

The grain size analysis and its distribu- 
tion is a fundamental descriptive measure for clastic sediments. The results of statistical parameters a graphic mean $\left(\mathrm{M}_{\mathrm{z}}\right)$ lies in coarse and medium sand size classes represented by $70 \%$ and $30 \%$, respectively, inclusive graphic standard deviation $\left(\sigma_{\mathrm{I}}\right)$ could be categorized in the poorly sorted class and moderately sorted represented by $75 \%$ and $25 \%$ respectively, inclusive graphic Skewness $\left(\mathrm{Sk}_{\mathrm{I}}\right)$ could be categorized in fine skewed, near symmetrical, and strongly fine skewed classes represented by $55 \%, 40 \%$, and $5 \%$, respectively, and inclusive graphic Kurtosis $\left(\mathrm{K}_{\mathrm{g}}\right)$ could be categorized in the platykurtic, mesokurtic, very lepto kurtic and lepto kurtic classes represented by $35 \%, 25 \%, 15 \%$ and $25 \%$, respectively.

The average content of total heavy minerals is $4.5 \%$ and the heavy content ranging from $2 \%$ and $10.5 \%$. Opaque minerals represented by Magnetite, Hematite, Ilmenite constituents have an average $1.07 \%, 0.1 \%$ and $0.286 \%$ respectively. Abrasive minerals as Garnet constituents has an average $0.13 \%$ and pigment minerals as Rutile and Titanite constituents have an average of $0.188 \%$ and $0.23 \%$ respectively. Radioactive minerals as Fluorites, Zircon, and Thorite constituents have an average of $0.0075 \%, 0.184 \%$ and $0.001 \%$, respectively. Amphiboles and Pyroxene constituents range from $0.1 \%$ to $3.78 \%$ with an average of $2.22 \%$.

The eU contents range between 1 and $4 \mathrm{ppm}$ with an average $1.76 \mathrm{ppm}$, while eTh is between 2 and 29ppm for with an average $10.75 \mathrm{ppm}$. The average Ra average content for these sediments is $2.89 \mathrm{ppm}$, and the average content of $\mathrm{K} \% 1.16 \%$.

The concentration of minerals restricted in the west (upstream) and the east (downstream) parts of the area due to the present of acidic rocks and the geomorphology of wadis. The low concentration restricted in the center part of the area where the rocks represented by basic rocks (volcanics, metavolcanics, and gabbros).

The transportation agent is rare and consid-

er seasonal so the sediment restricted near the source rock and transported short distance.

\section{REFERENCES}

Abdel-Rahman, A.M., 1990. Petrogenesis of earlyorogenic diorites, tonalites and post-orogenic trondhjemites in the Nubian shield. J. Petrol., 31, 1285-1312.

Abdel-Rahman, A.M., 1995. Tectonic-magmatic stages of shield evolution: the Pan-African belt in northeastern Egypt. Tectonophysics, 242, 223-240

Akaad, M.K.; El-Gaby, S., and Habib, M.E., 1973. The Barud Gneisses and the origin of Grey Granite. Bull. Fac. Sci. Assiut Univ. ,2, 55-69.

Bea, F.; Pereira, M. D.; Corretage, L. G., and Fershtater, G. B., 1994. Differentiation of strongly peraluminous, perphosphorous granites: the Pedrobenards pluton, Central Spain. Geochemica et Cosmochemica Acta, 58, 2609:2627.

Bea, F., 1996. Residence of REE, Y, Th and U in granites and crustal protolith; implications for the chemistry of crustal melt. J. Petrol., 37, 521:552.

Berry, L. G.; Mason, B., and Deitrich, R. V., 1983. Mineralogy. Freeman, San Francisco.

Carey, E., and Brunier, B., 1974. Analyse théorique et numérique d'un model mécanique

élémentaire appliqué à l'étude d'une population de failles. C. R. Acad. Sci. Paris, D 279, 891-894.

Dardir, A.A.; Khalaf, I.; Matter, E., and Aziz, M. , 1987. Basement Rocks of Safajah Quadrangle, Egypt (NG36K5-6), 1:100,000 Geological Map, Egypt. Geol. Surv. Min. Author., Cairo, Egypt.

Dardir, A.A., and Abu Zeid, K.M., 1972. Geology of the basement rocks between latitudes 27_000 and 27 300N, Eastern Desert. Ann. Geol. Surv. Egypt II, 129-159.

El-Akkad, S., and Dardir, A.A., 1965. Geological map of the coastal strip between Qena-Sa- 
faga road and Wadi Sharm El Bahari, scale $1: 100,000$ (latitudes 25_450-26_450N and longitudes 33_440-34_250E) (Noted in the list of unpublished maps of the Egyptian Geological Survey by El Ramly (1972)).

El Gaby, S., and Habib, M. S., 1982. Geology of the area south-west of port Safaga with special emphasis on the granitic rocks, Eastern Desert, Egypt. Ann. Geol. Surv. Egypt, 12, 47-71.

El-Gharbawi, R.I.A., and Hassen, I.S., 2001. The Late Precambrian metagabbro- diorite complex, Wadi Melheg area, southeastern Sinai, Egypt: an active continental margin setting. Ann. Geol. Surv. Egypt, XXIV, 131-158.

El Ramly, M. F., and Akaad, M. K., 1960. The basement complex in the Central Eastern Desert of Egypt, between latitudes 2430 and $2540 \mathrm{~N}$. Geol. Surv. Egypt. Cairo, 8, 35p.

El Shazly, E. M., 1964. On the classification of the Precambrian and other rocks of magmatic affiliation in Egypt. Proc. XXII Inter. Geol. Congress, Sec., 10, 88-101.

Ewing, R. C., and Haaker, R. F., 1980. The metamict state: Implications for radiation damage in crystalline waste forms. Nuclear and Chemical Waste Management, I, 51-57.

Folk, R. L., and Ward, W. C., 1957. Brazos River bar: a study in the significance of grain size parameter. J. Sedim. Petrol., 27, 3-27.

Francis, M.H., 1972. Geology of the basement complex in the North Eastern Desert between latitudes 27_300 and 28_000N. Ann. Geol. Surv. Egypt ,II, 161-180.

Ghanem, M., 1972. Geology of the basement rocks north of latitude 28_N Eastern Desert Ras Ghareb area. Ann. Geol. Surv. Egypt, II, 181-197.

Ghoneim, M.F.; Takla, M.A., and Lebda, E.M., 1992. The gabbroic rocks of the central Eastern Desert, Egypt: a geochemical approach. Ann. Geol. Surv. Egypt ,XVIII, 1-22.

Habib, M.S., 1970. Preliminary geological map of the area south-west of Safaga, scale 1:100,000 (latitudes 26_200-26_400N and longitudes 33 $300-33 \_500 \bar{E}$ ) (Noted in the list of unpublished maps of the Egyptian Geological Survey by El Ramly (1972)).

Habib, M.E., 1972. Geology of the area west of Safaga, Egypt. Ph.D. Thesis, Univ. Assiut, Egypt.

Heinrich, E. Wm., 1958. Mineralogy and geology of radioactive raw materials. McGraw-Hell Book Company, Inc., 653p.

Hinton, R. W. and Paterson, B. A., (1994): Crystallization history of granitic magma: evidences from trace elements zoning. Mineral. Mag., Vol. 58A, P. 416:417.

Hume, W.F., 1934. Geology of Egypt II, (1) The Metamorphic Rocks, and (2) The Later Plutonic and Minor Intrusive Rocks. Government Press, Cairo.

Ivanovich, M.,1994. Uranium series disequilibrium: concept and applications. Radiochem. Acta, 64, 81:94.

Karavtchenko, G. T., 1960. Colouration of monazite. Akad. Nauk. USSR, Sibir., Octdec., No. 7, 80-90.

Masoud, M.S.; Youssef, M.M., and O'Connor, E.A., 1992. 1:250,000 Scale Geologic Map of the Al Qusayr Quadrangle, Egypt. Egypt. Geol. Surv. Min. Author., Cairo, Egypt.

Navas, A.; Soto, J., and Machin, J., 2002: ${ }^{238} \mathrm{U},{ }^{226} \mathrm{Ra}$, ${ }^{210} \mathrm{~Pb},{ }^{232} \mathrm{Th}$ and ${ }^{40} \mathrm{~K}$ activities in soil profiles of the Flysch sector (Central Spanish Pyrenees). Applied Radiation and Isotopes. 57, 579:589.

Pabst, A., 1952. The metamict state. Am. Mineral., 37, 137:157.

Palache, C.; Berman, H., and Frondel, C., 1944. Dana's system of mineralogy. $1,\left(7^{\text {th }}\right.$ edition $)$ Wiley, New York.

Sabet, A.H.; El-Gaby, S., and Zalata, A.A., 1972. Geology of the basement rocks in the northern parts of El-Shayib and Safaga Sheets, Eastern 
EL AZAB

Desert. Ann. Geol. Surv. Egypt,II, 111-128.

Speer, J. A., 1980. Zircon. In P.H. Ribble [2 ${ }^{\text {nd }}$ Ed.]. Reviews in Mineralogy 5: Orthosilicate Mineral Soc. Am., Washington D. C., 67-112.

Stern, R. J., 1981. Petrogensis and tectonic setting of late Precambrian ensimatic volcanic rocks, Central Eastern Desert of Egypt. Precambrian Res., 16, 195-230.

Wenk, H. R., and Bulakh, A., 2004. Minerals; their constitutions and origin. Syndicate of The University of Cambridge Press.

\section{دراسات معدنية واشعاعية لرواسب وادى ابوهمر-سفاجا ـوسط الصحراء الثرقيةــ}

$$
\text { اشرف العزب ابراهيم }
$$

منطقة الدراسة مغطاه بصخور نارية ومتحولة ممثلة بالجابرو المتحول والبركانيات

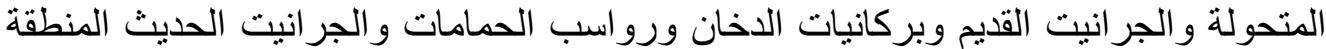

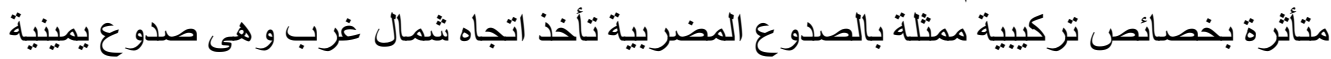

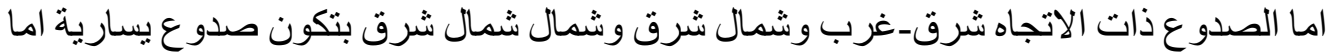

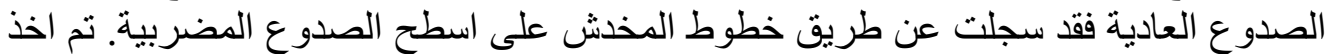

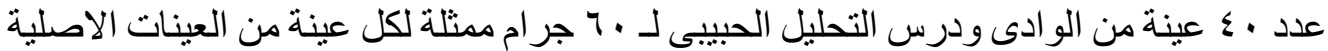

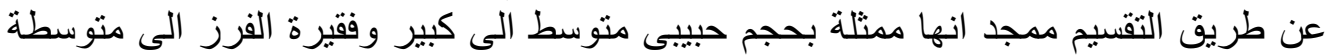

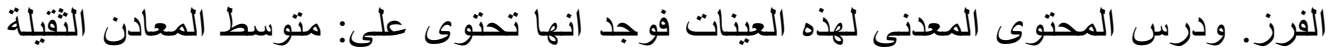

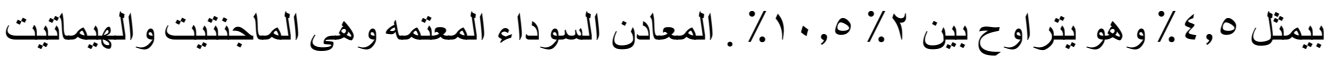

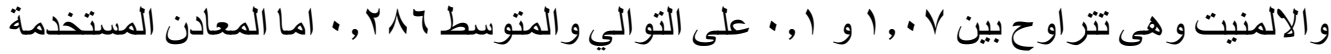

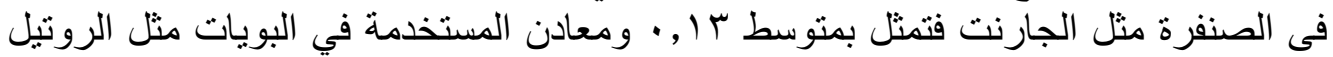

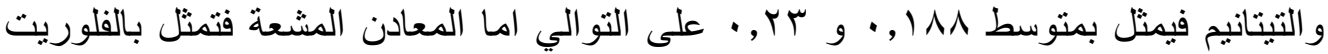

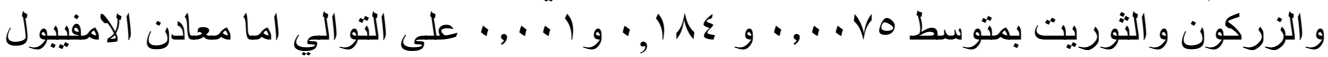

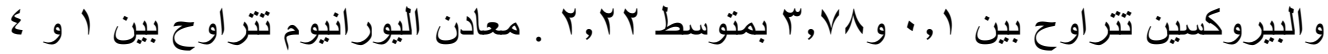

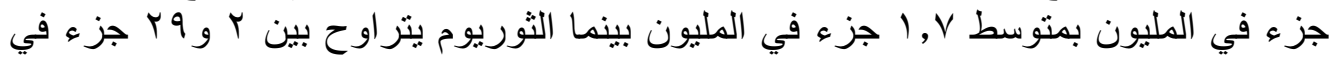

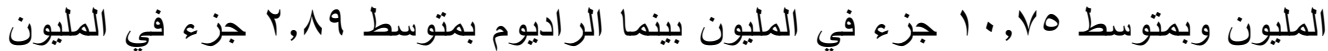
و البوتاسيوم يمنل 17 , 1) 1. 